\title{
الإقناع بما نقله الخطيب عن شيخه العتيقي بالقول والتحديث والسؤال والسماع
}

\author{
إعداد الدكتور \\ سيد جابر سيد أحمد الشيمي \\ الأستاذ المساعد في قسم الحديث وعلوميكه \\ بكليتاصول الدينوالدعوة بأسيوط-جالمعتشالأزهر
}





\section{الإقناع بما نقله الخطيب عن شيخه العتيقي}

\section{الإقناع بما نقله الخطيب عن شيخه العتيقي}

بالقول والتحديث والسؤال والسماع

$$
\text { سيد جابر سيد أحمد الثيمي }
$$

قسم الحديث وعلومه ، كلية أصول الدين والدعوة بأسيوط - جامعة الأزهر -

مصر .

$$
\text { البريد الإكتروني: saidahmed48@azhar.edu.eg }
$$

الملخص

البحث يركز على الرواة المترجم لهم من قبل الخطيب البغدادي والناقل فيهم

كلام شيخه العتيقي بصيغة حدثنا، سمعت، قال لي، أو قال العتيقي، والسؤال منه على بعض الرواة لله ، وقد اعتمدت على كتاب تاريخ بغداد للخطيب البغدادي ، والبحث يتكون من: مقدمة ومبحثين وخاتمة ،أمـا المقدمة ففيها فكرة البحث ومشكلة

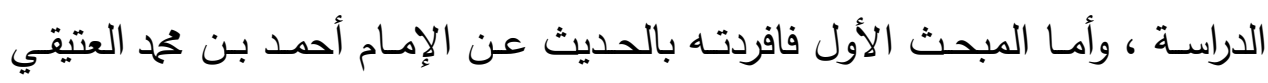
بترجمة موسعة، وأما المبحث الثاني فجمعت فيه الرواة المترجم لهم من قبل الخطيب البغدادي والناقل فيهم كـلام شيخه العتيقي ، وقد ورتبت الرواة المترجم لهم على حسب حروف الهجاء حسب ورودها في تاريخ بغداد، وقد نبهت على أقوال الأئمة في الرواة عقب ذكر قول العتيقي الذي نقله الخطيب بالصيغ المذكورة ، وقارنت بين

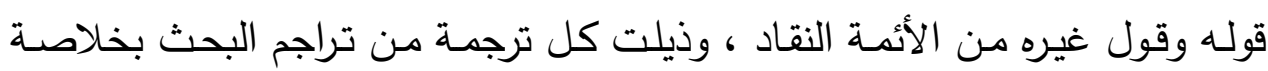

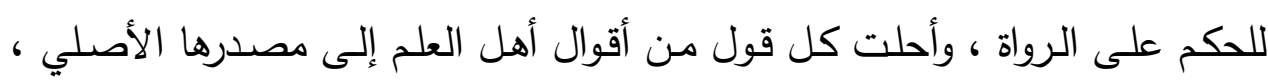
وأشرت إلى بيان وتوضيح نسبة كل راوٍ من الرواة ـ

الكلمات المفتاحية : الخطيب البغدادي - العتيقي - الرواة - تاريخ بغداد -

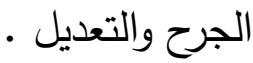

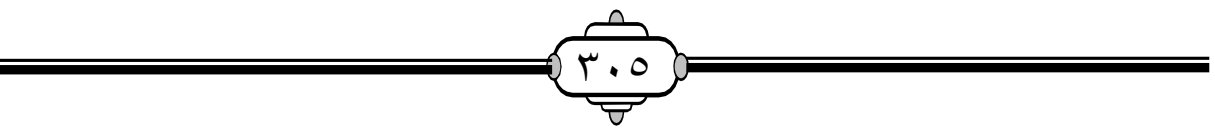


الإقناع بما نقله الخطيب عن شيخه العتيقي

\section{Persuasion of what $\mathrm{Al}-\mathrm{Khatib}$ narrated on the authority of}

his Sheikh Al-Ateeqi By saying, updating, questioning,

\section{and listening}

Syed Jaber Syed Ahmed El-Shimy Department of Hadith and its Sciences, Faculty of Fundamentals of Religion And the call in Assiut - Al-Azhar University.

\section{Email:}

\section{Abstract}

The research focuses on the narrators translated for them by $\mathrm{Al}$-Khatib $\mathrm{Al}$-Baghdadi, and the transmitter in them is the words of his sheikh Al-Ateeqi in the form of our story, I heard, he said to me, or Al-Ateeqi said, and the question from him to some of his narrators .

I relied on the book The History of Baghdad by al-Khatib alBaghdadi, and the research consists of: an troduction, two chapters, and a conclusion. Al-Baghdadi and the transmitter about them are the words of his sheikh Al-Atiqi, and the narrators have arranged the translator for them according to the letters of the alphabet according to their occurrence in the history of Baghdad.

And I compared his saying with that of other critical imams, and each translation of the research was appended with a summary to judge the narrators, and I referred every saying of

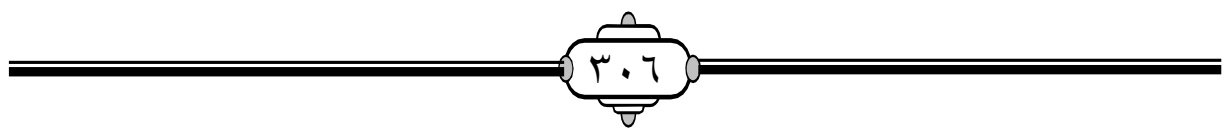


the scholars to its original source, and I referred to a statement and clarification of the ratio of each narrator from the narrators. Keywords: Al-Khatib Al-Baghdadi - Al-Atiqi - Narrators History of Baghdad - Al-Jarh and Tadheel.

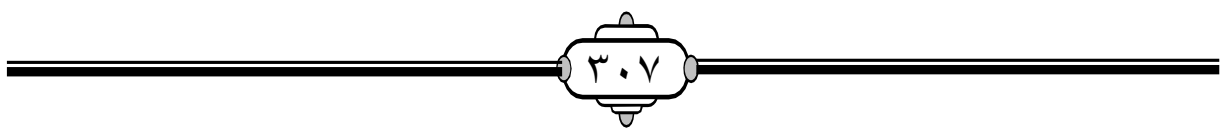




\section{الإقناع بما نقله الخطيب عن شيخه العتيقي}

\section{الاقدهمة}

الحمد لله الباقي بعد فناء خلقه، الكافي من توكل عليه، القيوم الذي ملكوت كل شيء بيديه، حمدًا كثيرًا طيبًا مباركًا فيه كما ينبغي لجلال وجهه وعظيم سلطانه، وأشهد أن لا إله إلا الله وحده لا شريك له، وأثهد أن محمدًا عبده ورسوله أرسله رحمة للعالمين، وخاتمًا للنبيين وحرزًا للأميين وإمامًا للمتقين بأوضح دليل، وأفصح تنزيل، وأفسح سبيل، وأفسر بيان، وأبهر برهان، وابعثه مقامًا محمودًا، يغبطه به بهان الأولون والآخرون وصل عليه وعلى آله الطيبين وصحابته الهجاهدين وأزواجه أمهات المؤمنين، أما بعد:

فإن القارئ المتمعن لكتاب تاريخ بغداد للخطيب البغدادي يجد فيه من أقوال أهل العلم والنقد لرواة جمعهم الخطيب في تاريخه، حيث إن مؤلفه ذكر من أخبار محدثيها وقُطَّانِهَا من العلماء من غير أهلها ووارديها من العلماء والمحدثين، وهو إذ مهن يذكر قوله في بعض الرواة، ويضيف من أقوال غيره من الأئمة في الكثير الغالب منهم ويكثر النقل عن مشايخه الكثير الأغلب مسندًا وغير مسند، ومن هؤلاء المشايخ الذي أكثر من نقل قوله مسندًا الإمام أحمد بن ححمد العتيقي والذي أكثر من النقل عنه بصيخ كثيرة متعددة منها صيغة أخبرنا، والتي تعد من أرفع صيخ الأداء عند التحمل، وقد خصصنا ذلك ببحث مستقل، ثم أردفناه ببحث آخر. لكن صيغ الأداء عنه مختلفة منها صيغة حدثنا، وسمعت، وقال لي، وسؤاله عن بعض الرواة فاستعنت الله، وجمعت هذه الأقوال المثبت فيها الصيخ السابقة وجميعها من كتاب لهن تاريخ بغداد في هذا البحث المتواضع ذاكرًا قول الإمام العتيقي مقارنًا قوله بغيره من أقوال أهل العلم مثبتًا له عنوانًا بـ [الإقناع بما نقله الخطيب عن شيخه العتيقي بالقول والتحديث والسؤال والسماع].

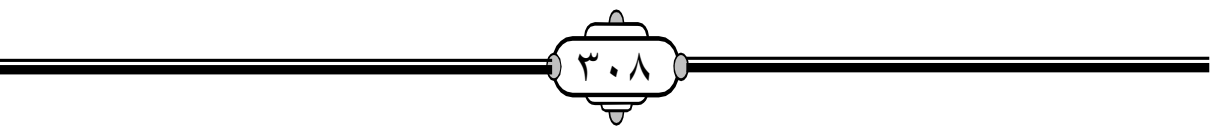




\section{خطة البحث}

البحث يتكون من: مقدمة ومبحثين وخاتمة.

أما المقدمة فذكرت فيها الحمد والثناء على الله عز وجل، والصلاة والسلام على وملى والى أشرف الخلق، والترضي على الصحابة وأزواج أمهات المؤمنين، مع توضيح فكرة البحث وكيف جاءت ؟ وعلى أي الكتب اعتمدت ؟ ومع أي إمام أعيش دعه في البحث ؟ وتسميته بما ذكرت.

وأما المبحث الأول فافردته بالحديث عن الإمام أحمد بن ححم العتيقي بترجمة موسعة.

وأما المبحث الثاني فجمعت فيه الرواة المترجم لهم من قبل الخطيب البغدادي والناقل فيهم كلام شيخه العتيقي بصيغة حدثنا، سمعت، قال لي، أو قال العتيقي، والسؤال منه على بعض الرواة له، وعنونته بالتراجم التي ذكرها الخطيب البغدادي لأقوال شيخه العتيقي بصيغة التحديث، والسماع والقول، والسؤال وبلغوا تسع وستون راوياً، وكان منهجي في الجمع لهم الآتي:

ا. اعتمدت على جمع رواة البحث على كتاب تاريخ بغداد للخطيب البغدادي. r. رتبت الرواة المترجم لهم على حسب حروف الهجاء حسب ورودها في تاريخ بغداد.

r. اكتفيت بالرواة الذين قال فيهم الخطيب: حدثنا، سمعت، قال لي، قال العتيقي: والسؤال منه على بعض الرواة له. ع. اعتمدت في التعريف بالرواة اسمًا ونسبًا ووصفًا، ذكر بعض الشيوخ

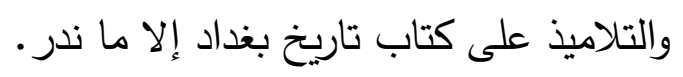

ه. اكتفيت بذكر شيخين من شيوخ الراوي وتلميذين من تلاميذه مضيفًا عقبهما وغيرهما.

7. صدرت قول العتيقي بالصيخ الواردة عنه بعد ذكر الاسم والنسب، أو

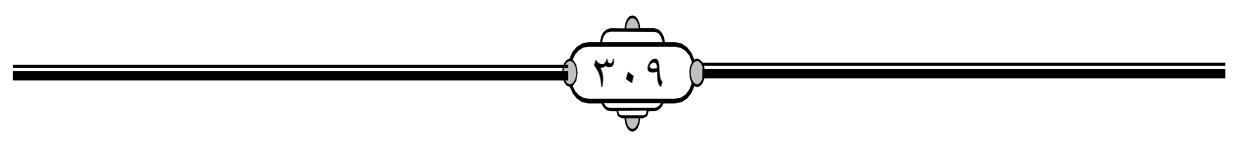


الوصف، وبعض الثيوخ والتلاميذ للرواة المترجم لهم. V. نبهت على أقوال الأئمة في الرواة عقب ذكر قول العتيقي الذي نقله الخطيب بالصيخ المذكورة. ^. ق قارنت بين قوله وقول غيره من الأئمة النقاد. 9 9. ذيلت كل ترجمة من تراجم البحث بخلاصة للحكم على الرواة. • ا ـ أحلت كل قول من أقوال أهل العلم إلى مصدرها الأصلي. ا 1 ـ أشرت إلى بيان وتوضيح نسبة كل راوٍ من الرواة. r ا ـ نبهت إلى مصادر التراجم بالهامش دون ذكر الطبعات. با ـ أخرت ذكر الطبعات وتتمة اسم المصدر إلى نهاية البحث. ع ا. تتاولت في نهاية البحث النتائج التي توصلت إليها وأهم التوصيات من

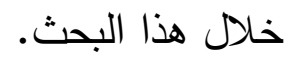
1 ـ ذيلت البحث بفهارس علمية تخدم القارئ له: أ- فهارس الرواة المترجم لهم. ب- فهارس المصادر التي اعتمدت عليها في البحث. و الله أسأل لنا ولجميع المسلمين مزيد التوفيق ورقي أخلاق أهل العلم المخلصين وآخر دعوانا أن الحمد لله رب العالمين. 


\section{المبحث الأول}

\section{ترجمة الإهام أحمد بن هممد العتيقي}

أحمد بن حمد بن أحمد بن ححمد بن منصور أبو الحسن المجزز المعروف العتيقي روياني الأصل، ولد ببغداد وبكر في سماع الحديث من علي بن حمح بن كيسان

وإسحاق بن سعد النسوي وغيرهما، الكثير (').

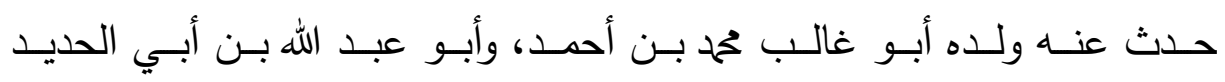

وعبد المحسن بن حمه الشيحي وغيرهم (؟). قال الخطيب البغدادي كتبت عنه وكان صدوقًا وسألته عن مولده فقال ولدت وكيت صبيحة يوم الخميس التاسع عشرة من المحرم سنة سبع وستين وثلاث مائة قلت له فالعتيقي نسبة إلى إيش فقال: كان بعض أجدادي يسمى عتيقًا فنسبها إليه وقال: سمعت أبا القاسم الأزهري ذكر أبا الحسن العتيقي فأثنى عليه خيرًا ووثقه (־). وقال السمعاني: كان أحد الثقات المكثرين في الحديث رحل إلى الثـام وديار مصر وسمع الحديث الكثير ، روى عنه: أبو بكر أحمد بن علي بن ثابت الخطيب الحافظ وذكره في التاريخ وأثنى عليه (ء). وقـال ابـن مـاكولا: قـال لـي شـيخنا العتيقي: إنـه رويـاني الأصـل، خـرج على الصحيحين، وكان ثقة متقنًا يفهم ما عنده (०). وقال الذهبي: وهو الذي يقول فيه الخطيب: أخبرنا حديث أحمد بن أبي جعفر

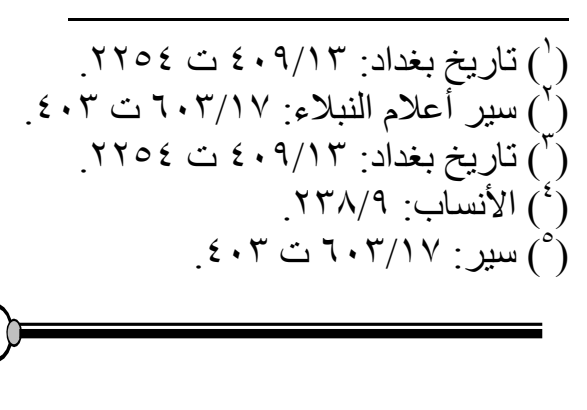


القطيعي(') وقال الذهبي: وكان الخطيب ربما دلسه يقول أخبرنا أحمد بن أبي جعفر القطيعي (ץ) توفى سنة إحدى وأربعين وأربعمائة(؟).

وقال الذهبي: وقع في أجزاء من حديثه، وله وفيات في جزء كبير (ء).

وقال ابن كثير : كان صدوقًا (0)، وقال ابن حجر : أحد حفاظ بغداد(")، وقال ححمد

محمد بن عبد الغني البغدادي أبو بكر في تكملة الإكمال: الحافظ سمع الكثير، وحدث

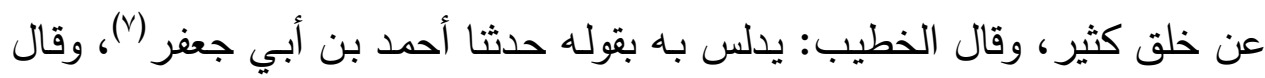

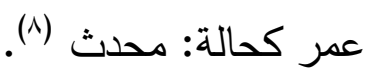

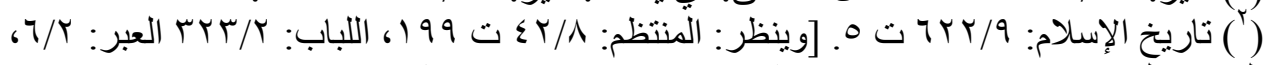

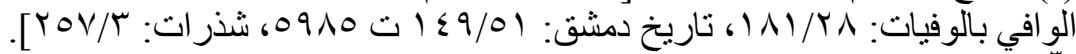

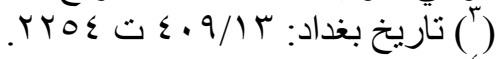

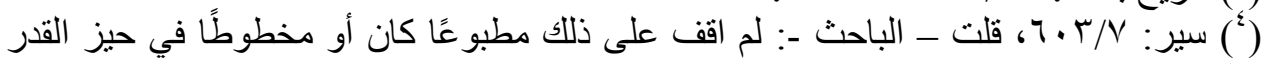

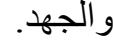

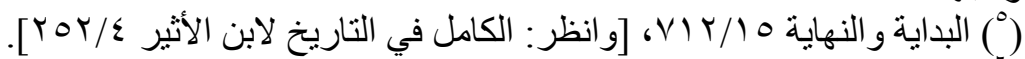

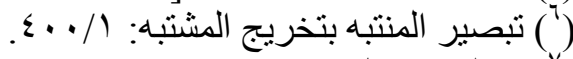

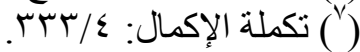

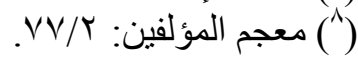




\section{المبحث الثاني}

الرواة الذين نقل الغطيب البغدادي أقوال شيخه العتيقي بافظ (القول، والتمديث، والسؤال، والسماع)

1- محمد بن أحمد بن أبي حسان أبو الحسن المؤدب(')، حدث عن: أبي العباس ابن

عقدة الكوفي وإسماعيل بن حمد الصفار وغيرهم(ب). وقال الخطيب: حدثي عنه أحمد بن ححم العتيقي، وقال لي: كان ينزل دار ابن

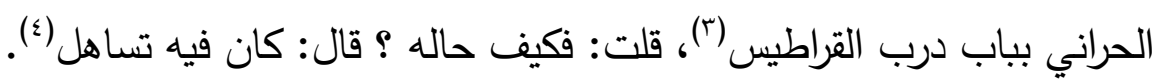

\section{فاصة حال الراوبs:}

هكذا نقل الخطيب قول العتيقي بصيغة الأداء التي هي من طرق التحمل والأداء، وهي صيغة حدثني والتي تدل على السماع المباشر من الثيخ للتلميذ، لكن مفاد القول بعد ذكر صيغة الأداء لا تدل على قبول الراوي والذي انفرد بذلك القول في الراوي الإمام العتيقي لكن عدم القبول مع التقرد ثابت لكن إذا توبع بمثله أو لأ أقوى منه ارتقى من درجة الضعف إلى ما فوقه والله أعلم.

\section{r - محمد بن جعفر بن محمد بن هارون بن فروة بن ناجية بن مالك أبو الحسن التميمي}

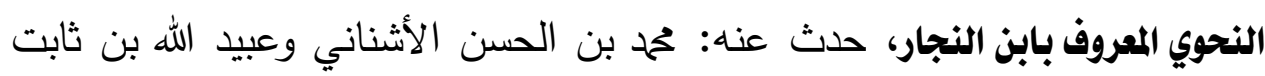
الحريري وغيرهما، وعنه: حمحم بن علي بن مخلد الوراق، وأبو القاسم الأزهري

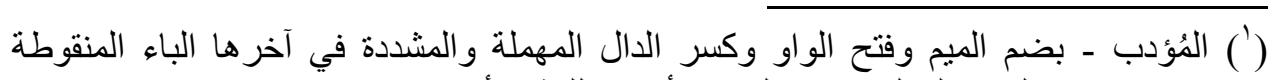

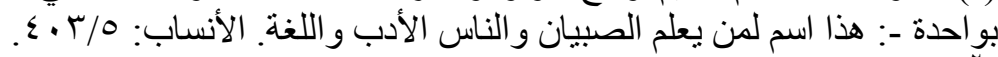

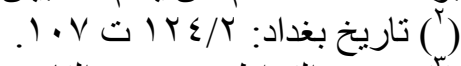

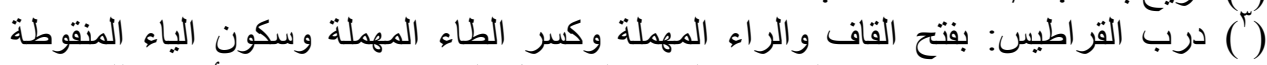

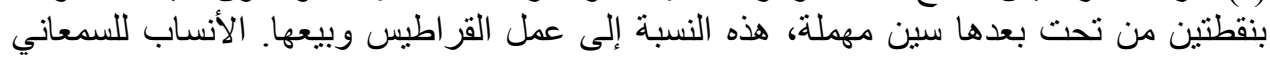
(ro9/1) (1)

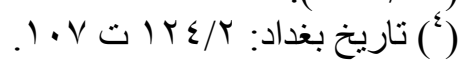




\section{الإقتاع بما نقله الخطيب عن شيخه العتيقي}

وغيرهما، قال الخطيب: قال العتيقي: ثقة(') توفى سنة اثنتين وأربعمائة بالكوفة(؟) ونقل الذهبي توثيق العتيقي(r) وقال السمعاني: كان ثقة(أ) ونقل الذهبي توثيق العتيقي(ه) وذكر ابن الجوزي قول العتيقي(؟) وقال ياقوت الحموي: قال الخطيب: وهو ثقة [وهذا وهم منه بل القول قول العتيقي وليس قول الخطيب والله أعلم](V) ونقل ونقل ابن العماد توثيق العتيقي (^).

\section{خلاصة مال الراوي:}

أخذ الخطيب قول شيخه العتيقي مباشرة بصيغة قال دون واسطة، وفيه من الدقة ما فيه ووافق على هذا التوثيق السمعاني صراحة والذهبي ضمنيًا بنقل قول العتيقي في كتبه، والذي يعني الموافقة على ذلك وخاصة أنه لم يذكر عنه أي اعتراض أو نقد أو مراجعة وكذللك نقل ووافق على هذا التوثيق ابن العماد الحنبلي فالراوي مقبول الرواية بقول العتيقي، ومن وافقه دن الأئمة الأعلام و الله أعلم.

r- محمدل بن الحسن بن سُسليم أبوبكر النجاد(9)، سمع أبا العباس بن عقدة، و مححد بن بن جعفر المطيري وغيرهما، وعنه: أبو القاسم الأزهري وأحمد

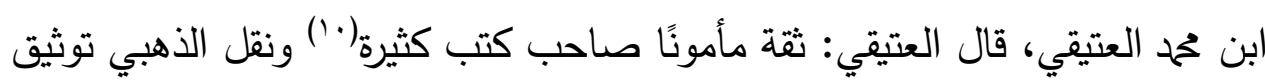

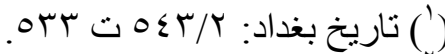

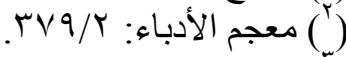

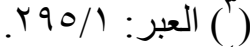

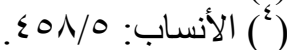

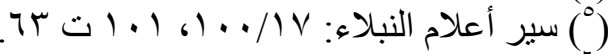

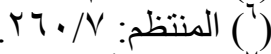

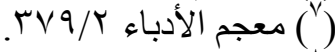

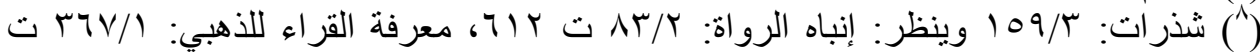

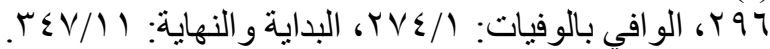

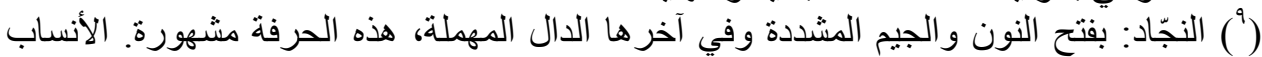

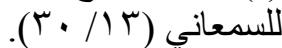

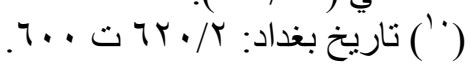




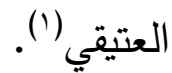

\section{فلاصة مال الراوي:}

انفرد العتيقي بتوثيق الراوي ونقل ذلك التوثيق الذهبي وجاء نقل الخطيب هذا القول بصيغة القول الذي يدل على الأخذ المباشر من شيخه العتيقي، وهكذا نجد أن الخطيب تأثر بشيخه ووافق على قوله ووافقهما ضمنيًا الإمام الذهبي في توثيق ليقي الراوي وقبوله و الله أعلم.

ع - محمدل بن الصقر بن يحيى بن السري بن ثروان أبو بكر الموصلي عم شيخنا محمد بن هماه

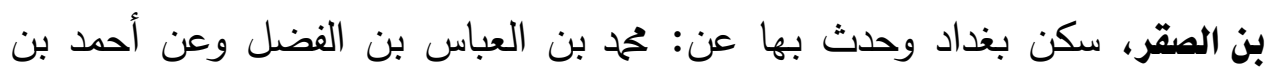
جعفر بن أبي توبة الثيرازي حدثني عنه أحمد ابن حمد العتيقي وقال لي: كان بن بن

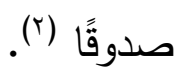

\section{فاصة مال الراوبي:}

يتضح من السابق أن الخطيب نقل التحديث عن شيخه والقول في ذكر توثيقه للراوي حيث أورد صيغة التحديث في الرواية عنه، وإنه من شيوخه وإنه قال له: عن لن هذا الراوي ثقة، وهكذا انفرد العتيقي بتوثيق ذللك الراوي فيما وقفت عليه من كتب التراجم حسب الجهد فهو بذلك مقبول الرواية و الله أعلم.

0- محمد بن عبد الله بن محمد بن إسحاق بن حسان أبو عبد الله الحريري(ّ)، سمع عبد

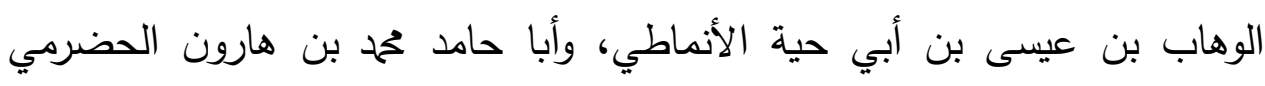
وغيرهما، وعنه: أحمد بن ححم العتيقي، والحسين بن جعفر السلماني، قال الخطيب: قال العتيقي: جميع ما كان عنده جزء واحد قال: كان ثقة (ء).

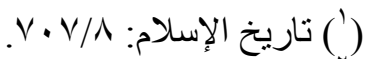

$$
\begin{aligned}
& \text { (r) }
\end{aligned}
$$

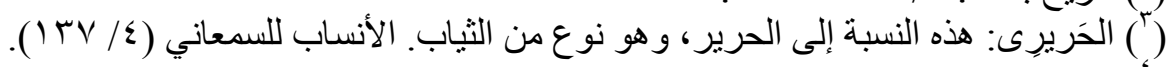

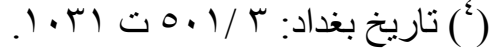




\section{فلاصة هال الراوي:}

انفرد العتيقي بتوثيق الراوي ونقل ذلك عنه الخطيب في تاريخه بصيغة قال، والتي هي من أرفع صيخ الأداء قبل التخصص لكن بعده استعملت في المذاكرة عن طريق السماع وسواء قبل التخصص أو بعده فهي إثارة إلى سماع ذلك القول من شيخه العتيقي فتوثيقه مقبول منفرد به من بين سائر الأئمة. و الله أعلم.

ج- محمد بن عبد الله بن الحسين أبو عبد الله الجعفي القاضي الكوفي المعروف بابن

الهرواني(')، سمع علي بن محمد بن هارون الحميري، ومحمد بن القاسم ابن زكريا

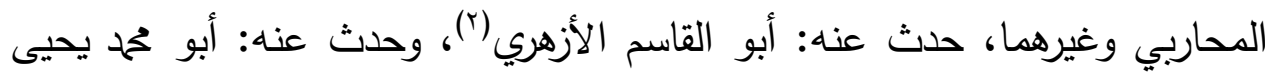
بن حمح بن الحسن العلوي(ّ)، قال الخطيب: حدثا العتيقي قال: توفى سنة اثتتين وأربع ومائة، قال العتيقي: ثقة صالح على مذهب أبي حنيفة ما رأيت بالكوفة

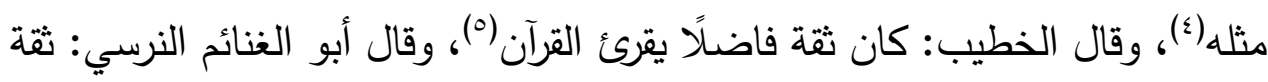
ثقة مأمون بقي على قضاء الكوفة سنين(؟) وقال السمعاني: ولي قضاء الكوفة وذهبت عامة كتبه وكان يحفظ حديثه وكان ثقة حسن المذهب(V)، وقال ابن الأثير: كان إمامًا فاضلً فقيهًا حنفيًا جليل القدر (^)، وقال ابن العماد الحنبلي: أحد الأئمة الأعلام في مذهب الإمام أبي حنيفة(9)، وقال الذهبي: أحد الأئمة الأعلام في

(') الهرواني و الهروي: بفتحتين إلى هراة مدينة بخر اسان. لب اللباب في تحرير الأنساب (ص: . (YVA

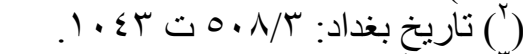

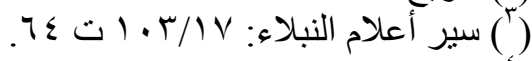

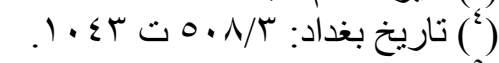
()

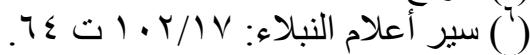

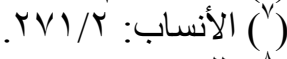

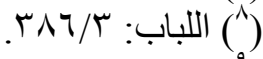

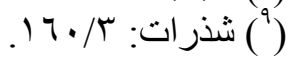




$$
\text { مذهب أبي حنيفة(') - (1) }
$$

\section{فاصة مال الراوي:}

اجتمع الأئمة على توثيق هذا الراوي ومن بينهم الإمام العتيقي نقله عنه الخطيب البغدادي بصيغة قال المؤكدة لسماع هذا التوثيق من العتيقي فالراوي مقبول محتج به و الله أعلم.

- - محمد بن عبد الله بن إسحاق أبو الفرج القاضي المعروف بالعماني(؟)، حدث عن: القاضي المحاملي، و محمد بن مخلد حدثنا عنه العتيقي وسألته عنه فقال: كان صالحًا ثقة لم يكن عنده إلا شيء يسير (r).

\section{فلاصة مال الراوي:}

لم أجد لذلك الراوي إلا قول الإمام العتيقي بسؤال الخطيب البغدادي له حيث فيه

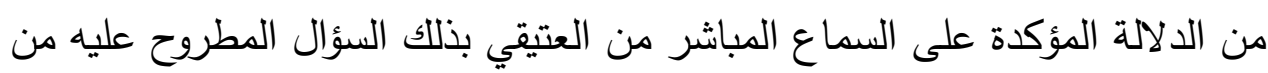
قبل الخطيب البغدادي. و الله أعلم.

\section{- - محمد بن عبد الله بن أحمد أبو بكر الجوهري سمع خيثمة بن سليمان الأطرابلس(؛)،} حدثي عنه: أحمد بن ححمد العتيقي وسألته عنه فقال: كان شيخًا ثقة صالحًا، وقال لي: اكتب عنه فإنه شيخ صالح يقال إنه مستجاب الدعوة منذ أربعين سنة (०).

فلاصة هال الراوي:

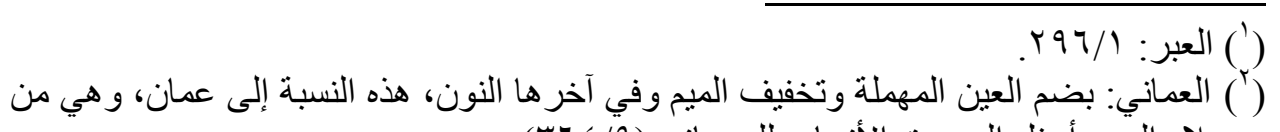

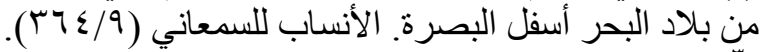

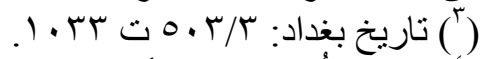

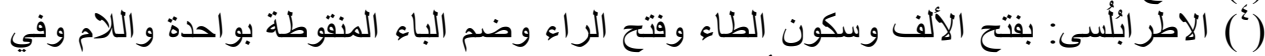

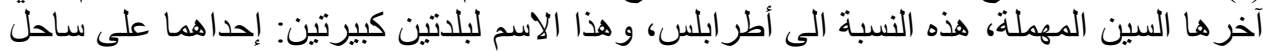

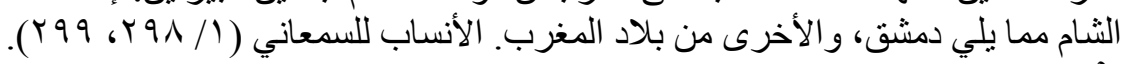

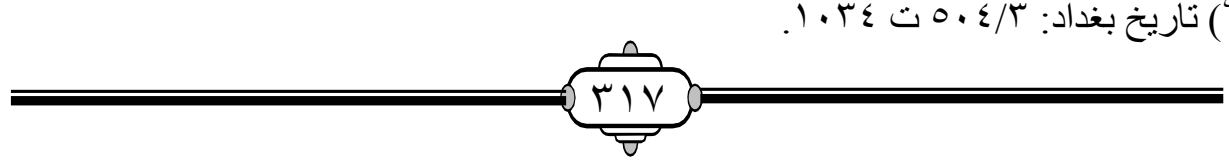




\section{الإقتاع بما نقله الخطيب عن شيخه العتيقي}

توضيح مكانة هذا الراوي جاء بطريق السؤال من التلميذ والإجابة من الشيخ فكانت الإجابة مقرونة بكون الراوي ثقة مقبول الرواية مستجاب الدعاء مع الإذن له بالكتابة عنه واستحق القبول والاحتجاج به. و الله أعلم.

9- محمد بن عبد الله بن أحمد بن القاسه بن جامع أبو أحمد الدهان ( ')، سمع: حمدويه

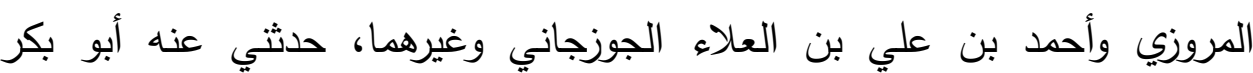
البرقاني وأبو القاسم الأزهري وغيرهما(r)، قال الخطيب: حدثني أحمد بن حمح العتيقي، قال: مات أبو أحمد بن جامع الدهان سنة تسع وتسعين وثلاث مائة، قال العتيقي: ثقة مأمون(ّ)، وقال الخطيب: سألت البرقاني عن أبي أحمد بن جامع فقال: كان شيخًا صالحًا ولم يزل يسمع معنا الحديث إلى أن مات قلت : أكان ثقة ؟ فقال: ثقة ثقة (๕)، وقال السمعاني: كان شيخًا صالحًا ثقة حريصًا على طلب العلم (॰)،

ونقل الذهبي توثيق العتيقي (؟).

\section{هل1صة مال الراوي:}

وافق العتيقي غيره من الأئمة على توثيق الراوي وقبوله وجاء قوله بنقل الخطيب عنه بصيغة حدثني، والتي هي من أرفع الصيغ التي يؤدي بها المحدثون عند التحمل فالراوي مجمع على توثيقه وتمكنه وقبوله. و الله أعلم.

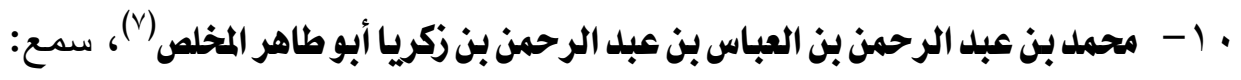

(1) الدهان - بفتح الدال المهملة و الهاء المشددة في آخر ها النون -: هذا يقال لمن يبيع الدهن.

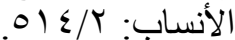
(

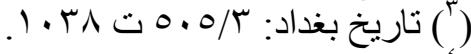

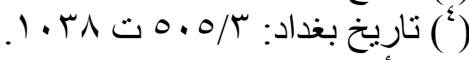
(0)

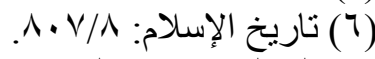
(v) المخلص: بضخ الإسلام الميم وفتح الخاء وكسر اللام المشددة وفي آخرها صاد: هذا يقال لمن يخلص

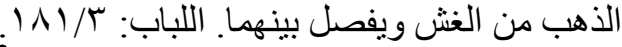




\section{الإقتاع بما نقله الخطيب عن شيخه العتيقي}

سمع: عبد الله بن محمد البغوي، ويحيى بن صاعد وغيرهما، حدث عنه: البرقاني والأزهري وغيرهما، قال الخطيب: حدثني أحمد ابن ححمد العتيقي قال: مات أبو طاهر المخلص سنة ثلاث وستين وثلاث مائة، وقال العتيقي: شيخ صالح ثقة (')، وقال الخطيب: كان ثقة(ז)، وقال الذهبي مخلص الذهب عن الغش(َ) وقال الذهبي: كان ثقة(؛)، وقال ابن الجوزي كان ثقة من الصالحين(*)، وقال ابن الأثير : بغدادي مكثر

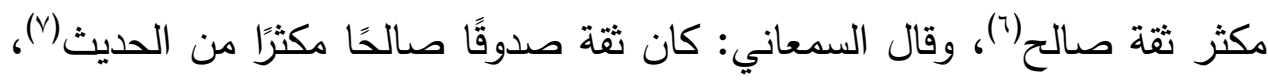
وقال ابن العماد الحنبلي: مسند وقته كان ثقة (^)ـ

\section{فاصة مال الراوي:}

وافق الخطيب شيخه في توثيق الراوي ونقل ذللك عنه هذا القول بصيغة التحديث التي تدل على التواصل المباشر بينه وبين شيخه في النقل عنه دون واسطة في ذلك وبجانب النقل عنه وافقه في التوثيق ووافقه غيره من الأئمة على قبول الراوي وتوثيقه و الله أعلم.

11 - محمد بن عبد الرحمن بن جعفر بن عمر أبو بكر الصوفي، حكى عن: أبي بكر

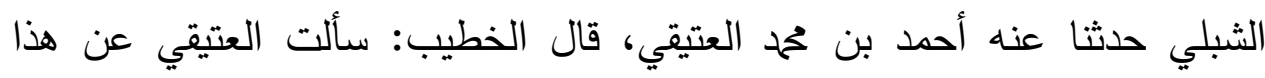
الشيخ فقال: كان شيخًا صالحًا صحبني قديمًا في طريق مكة وكان يحج ماشيًا (9)

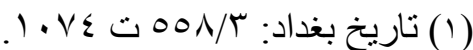

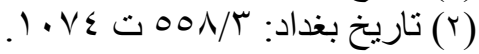

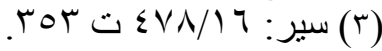

$$
\begin{aligned}
& \text { ( ) }
\end{aligned}
$$

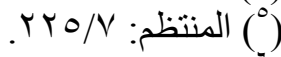

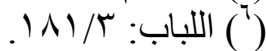

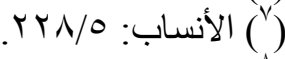

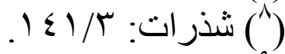

$$
\begin{aligned}
& \text { (") تاريخ بغداد: }
\end{aligned}
$$




\section{خلاصة مال الراوي:}

لم نقف لغير العتيقي كلامًا فيه وكان هذا النقل بواسطة السؤال من الخطيب لشيخه العتيقي عن حال هذا الراوي فكانت الإجابة مقبول الراوي وهذا انفراد من فن فئ العتيقي بهذا القول في ذلك الراوي. و الله أعلم.

r ا - محمد بن عمر بن علي بن خلف بن محمد بن زتببور بن عمرو بن تميه أبو بكر الوراق،

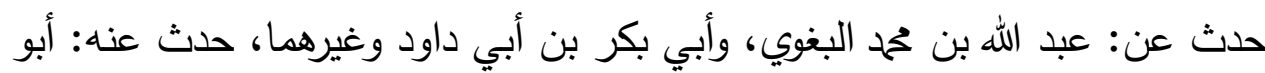

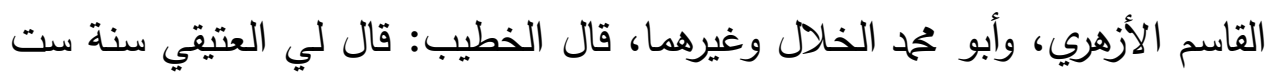
وتسعين وثلاث مائة فيها توفى أبو بكر مححد بن عمرو وكان فيه تساهل(')، وقال

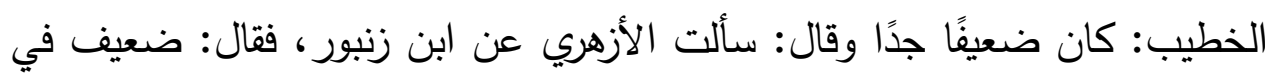
روايته عن ابن منيع وذكر أن سماعه من الدبي صحيح)(r)، وقال الذهبي: ضعيف(־)، وقال الذهبي: قال الخطيب: ضعيف جدًا(گ)، ونقل الذهبي كلام الأزهري الأزهري والعتيقي، والخطيب(0)، ونقل الذهبي كلام الأزهري، والعتيقي، والخطيب(؟)

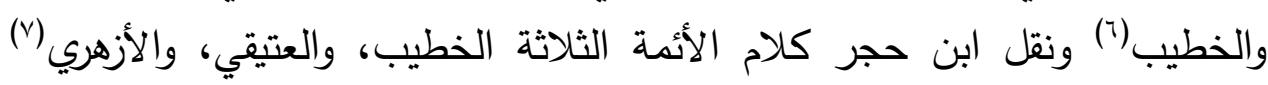

ونقل ابن العماد قول الخطيب (^).

\section{فل1صة مال الراوي:}

الجميع متفق على تضعيف هذا الراوي وعدم قبول روايته، وجاء قول العتيقي الذي نقله عنه الخطيب بصيغة القول عنه والذي أثبت فيه التساهل لهذا الراوي

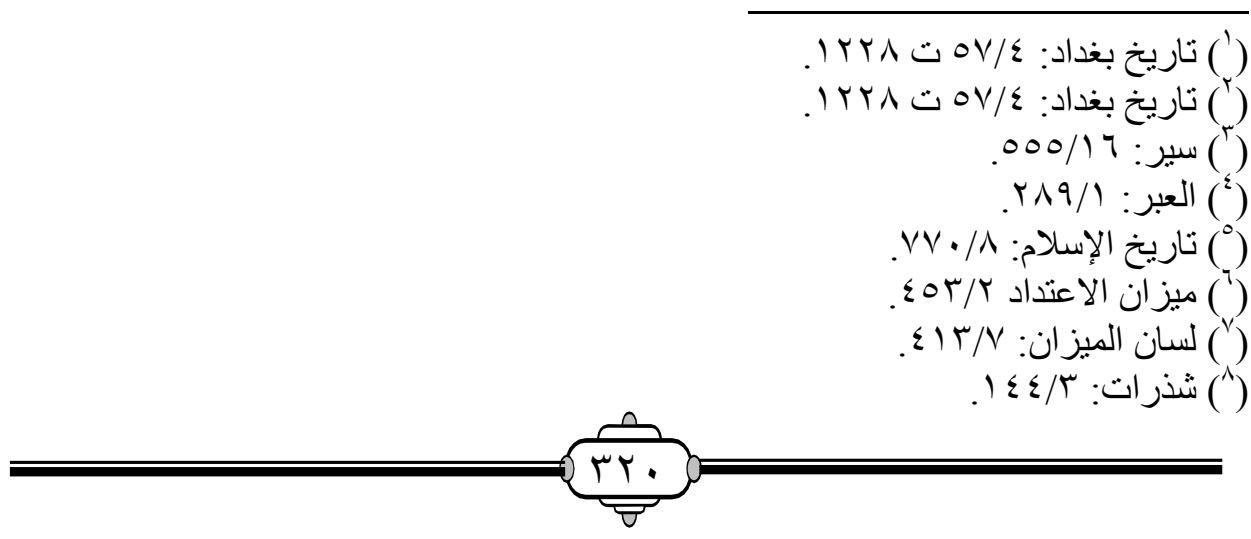


فوافق قوله قول جميع الأئمة بعدم قبول روايته، ويستثى من ذلك ما يقع من روايته

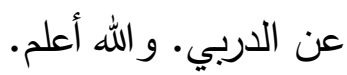

rا - محمد بن عثمان بن عبيل بن الخطاب أبو الطيب الصيدلاني، حدث عن:

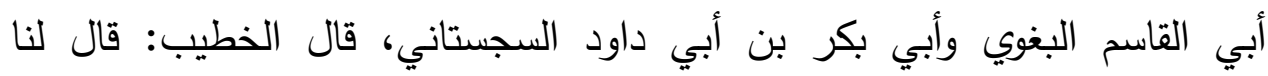
العتيقي: سنة أربع وثمانين وثلاث مائة بها توفى أبو الطيب الصيدلاني ثقة مأمون له أصول حسنة مضى على سداد وأمر جميل(') وقال ابن الجوزي: وكان ثقة مأمونًا

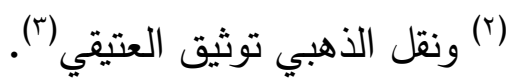

\section{فاصة مال الراوبي:}

هذا القول الذي ذكره الخطيب عن العتيقي يدل على أن النقل كان يجمع من التلاميذ وبينهم الإمام الخطيب والذي دل في تصريحه بقبول الراوي ووافقه غيره سواء على سبيل التصريح منهم أو القبول الضمني. و الله أعلم. ع ا - محمد بن علي بن عطية أبوطالب المعروف بالمكي، صنف كتابًا سماه قوت القلوب على لسان الصوفية وذكر فيه أشياء منكرة مستشنعة في الصفات، حدث عن: علي بن أحمد المصيصي وأبي بكر المفيد وغيرهما، حدث عنها محهد بن المظفر الخياط

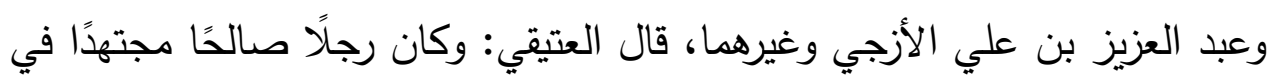

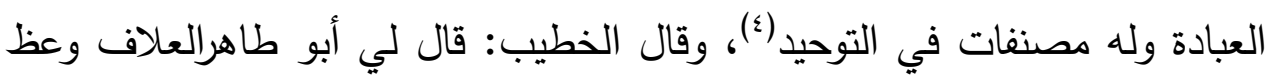
أبو طالب ببغداد وخلط في كلامه وحفظ عنه أنه قال ليس على المخلوقين أضر من الخالق فبدعوه وهجروه() وقال ابن كثير صنف كتابًا سماه قوت القلوب وذكر فيه

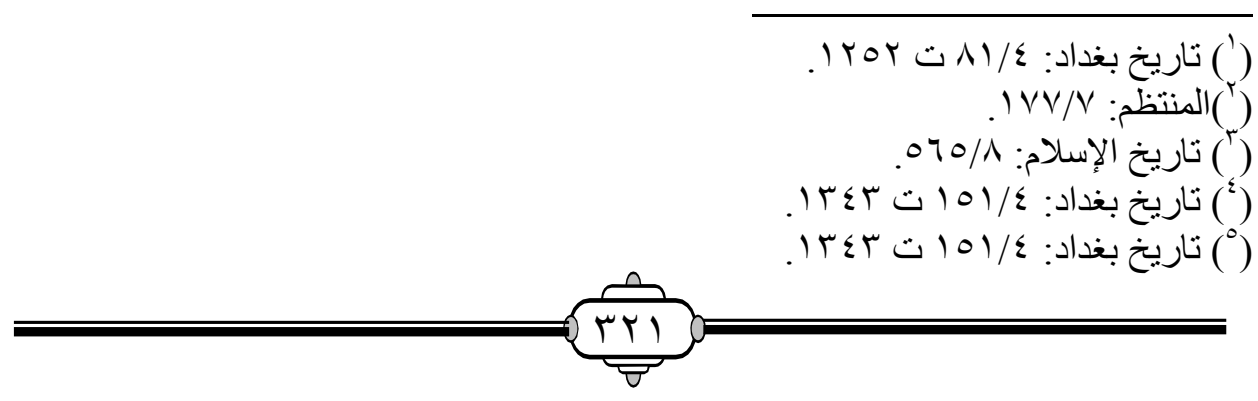


وقال ابن العماد: كان من الزهاد المتعبدين، وقال العتيقي: كان رجلًا صالحًا مجتهذًا صنف كتابًا سماه قوت القلوب وذكر فيه أحاديث لا أصل لها وطاف يعظ الناس في الجامع ببغداد(؟)، وقال ابن خلكان: صاحب كتاب قوت القلوب وكان رجلًا صالحًا مجتهدًا في العبادة ويتكلم في الجامع وله مصنفات في التوحيد ولم يكن من أهل مكة ولقي جماعة من المشايخ في الحديث وعلم الطريقة وأخذ عنهم(r)، وقال الذهبي: نشأ بمكة وتزهد وسلك ولقي الصوفية وصنف ووعظ وكان صاحب رياضة ومجاهدة(؛)، ونقل الذهبي: كلام أبو طاهر العلاف(0)، ونقل الذهبي كلام الخطيب وأبو طاهر العلاف وقال: توفى سنة ست وثمانين وثلاث مائة (؟). وقال اليافعي: كان في البداية صاحب رياضة ومجاهدة وفي النهاية صاحب

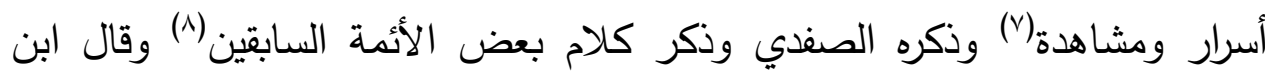
حجر: بعد ذكر كلام الخطيب وأبو طاهر العلاف وذكره ابن النديم في مصنفي

(9) المعتزلة (9)

\section{خلاصة حال الراوي:}

قول العتيقي الذي نقله الخطيب فيه دلالة على صلاح هذا الرجل لكنّ الصلاح وحده لا يفيد في قبول رواية الراوي فإذا أضيف إلى قول غيره من الأئمة نجد أن

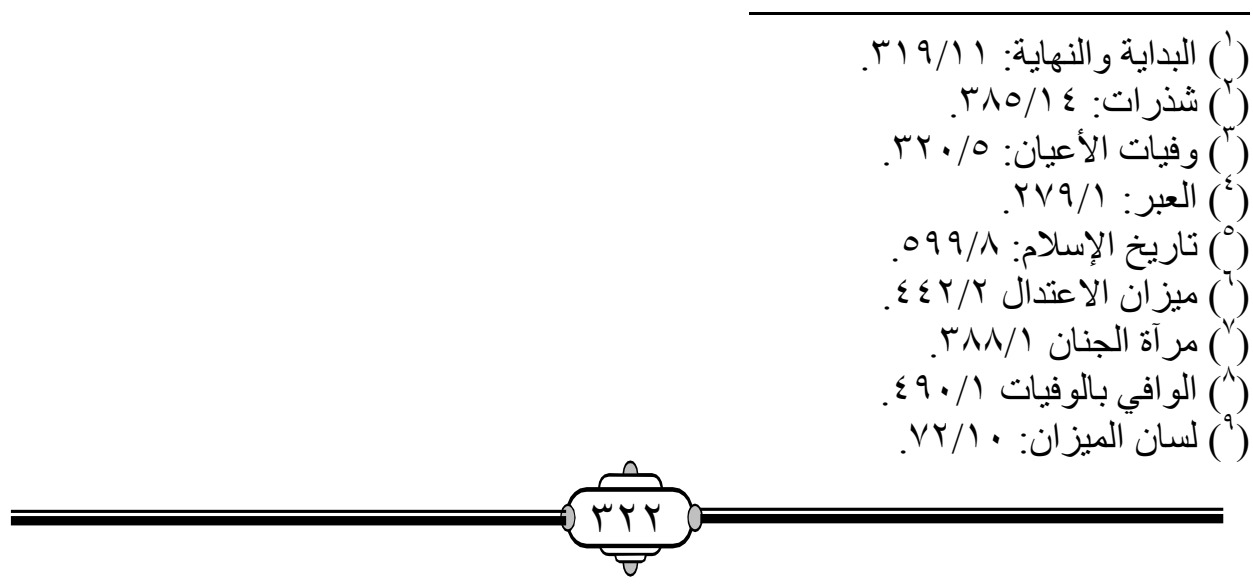




\section{الإقتاع بما نقله الخطيب عن شيخه العتيقي}

البعض وافقه في قضية صلاحه لكن حقيقة أمر الراوي هي عدم قبول روايته بانغراده فلابد له من متابع فيما يرويه وإلا كان ضعيفًا غير مقبول الرواية. و الله أعلم.

0 - - محمد بن علي بن يحيى بن عبل الله أبو بكر البزاريعرف بالعريف، حدث عن: أبي

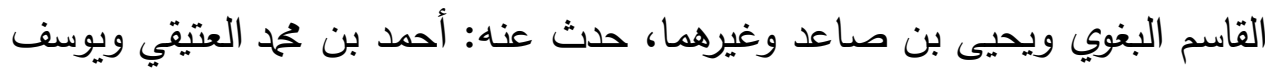
بن رباح البصري وغيرهما، قال الخطيب: سألت العتيقي عن أبي بكر العريف فقال:

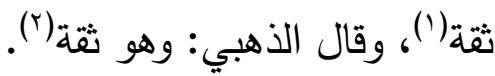

\section{خلاصة مال الراوي:}

سؤال الخطيب لشيخه عن حال هذا الراوي مفادها قبول هذا الراوي، ووافقه على ذلك الإمام الذهبي فالراوي مقبول الرواية محتج به. و الله أعلم. 7 ا - محمد بن علي بن القاسه أبو بكر الكرخي سكن بفداد، وحدث بها عن: عحم ابن عمرو البختري الرزاز، والحسن بن صفوان البرذعي وغيرهما، قال الخطيب: حدثا

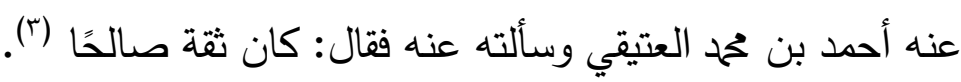

\section{فلاصة مال الراوي:}

الخطيب البغدادي نقل هذا القول عن شيخه بصيغة التحديث والتي هي أرفع صيخ الأداء عند التحمل من الثيخ، وانغرد العتيقي بهذا القول عن هذا الراوي فهذه منقبة منه فالراوي مقبول الرواية. و الله أعلم.

IV - محمدل بن العباس بن محمد بن زكريا بن يحيى بن معاذ أبو عمر الخزاز(؛) المعروف بابن

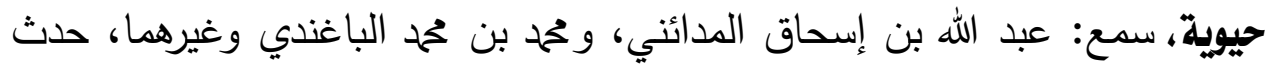

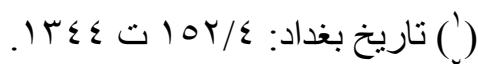

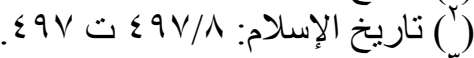

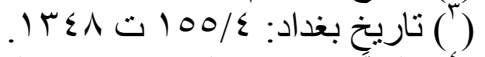

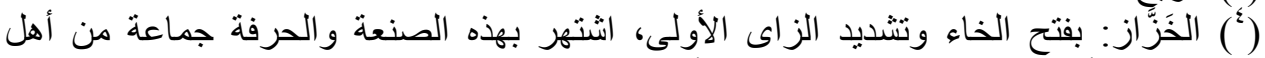
العر اقين من أئمة الدين و علماء المسلمين. الأنساب للسمعاني (1) (1) ). 


\section{الإقناع بما نقله الخطيب عن شيخه العتيقي}

عنه: أبو بكر البرقاني، وأحمد بن محمد العتيقي وغيرهما، قال الخطيب: سمعت

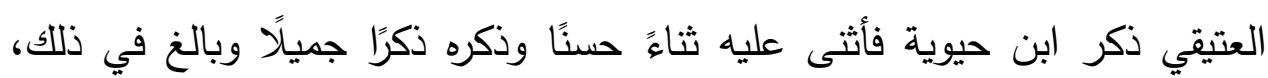

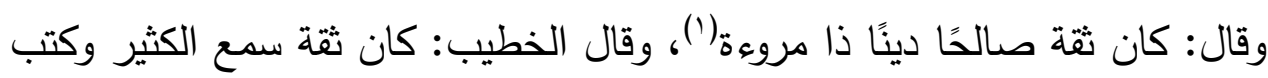
طول عمره وروى المصنفات الكبار (r) وقال الخطيب: حدثني الأزهري قال: كان أبو

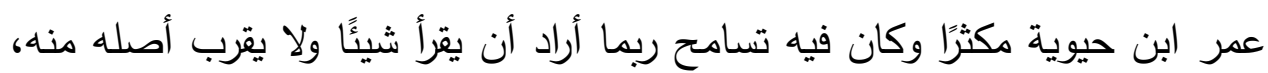
فيقرأ من كتاب أبي الحسن بن الرزاز لثقته بذلك الكتاب وإن لم يكن فيه سماعه وكان مع ذلك ثقة(؟) وقال الخطيب: سألت البرقاني عنه فقال: ثقة ثبت حجة(؛) وقال الذهبي: من علماء المحدثين توفى سنة اثثتين وثمانين وثلاث مائة(ه) وقال ابن الجوزي: انتقى عليه الدارقطني وكان ثقة دينًا كثير السماع كثير الكتابة للحديث كتب الكتب الكبار في الطبقات والمغازي وغير ذلك وكان ذا يقظة ومرورة (`). وقال الذهبي: من كبار محدثي بغداد(') وقال الصفدي: كان ثقة سمع الكثير وكتب طول عمره(^) وقال ابن أبي الفوارس كان فيه تساهل وفيه أرخه العتيقي وقال كان متيقظًا(9) وقال الذهبي المحدث الحجة(·) وقال ابن العماد، قال الخطيب: ثقة إنة كتب طول عمره وروى المصنفات الكبار (1').

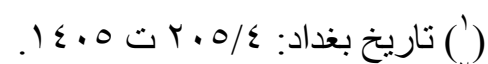

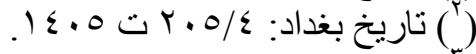

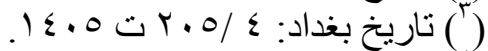

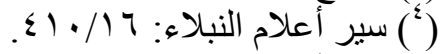

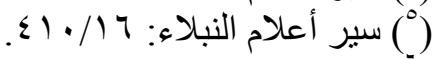

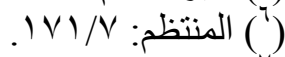

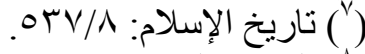

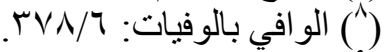

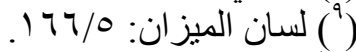

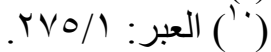

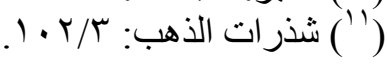


جاء توثيق هذا الراوي بوسيلة السماع المباشر من الثيخ للتلميذ ووافق قوله قول جميع الأئمة على قبول الراوي والاحتجاج به. و الله أعلم.

11 - محمدل بن محمد بن عمر بن أحمد بن خُشَيْش أبو أحمد، قال الخطيب: قال لي

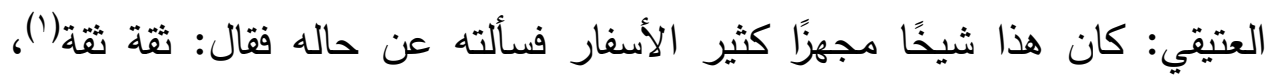
حدث عن: يزداد الكاتب، وأبي عبد الله المحاملي وغيرهما، روى عنه: هبة الله اللالكائي، وأبو الحسن العتيقي، ونقل الذهبي قول العتيقي (؟).

\section{فاصة مال الراوبي:}

هذا من دلائل الصلة القوية المتصلة بين الخطيب البغدادي والعتيقي حيث نقل الخطيب قول العتيقي في الراوي على سبيل العموم، ثم سأله عن حاله فأجاب له له لهابل بالتثبيت في الراوي وثقته وقبوله. و الله أعلم.

9 ا - محمد بن محمد بن عمر بن أحمد أبو الفتح، يعرف بابن أبي عمصير، حدث عن:

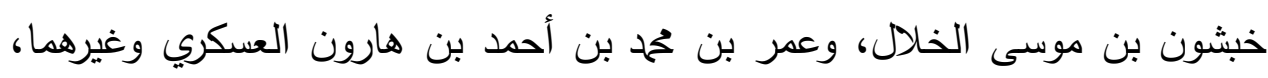
حدث عنه: أحمد بن حمح العتيقي، قال الخطيب: قال العتيقي: لي: كان شيخًا ثقة

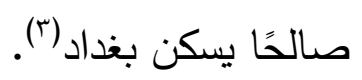

\section{فلاصة مال الراوبي:}

هذه المقولة من الخطيب عن العتيقي فيها دلالة على انفراد الخطيب بهذا القول له عن هذا الراوي ولم نجد لغيره من الأئمة كلامًا آخر فيه فانغراد العتيقي يدل على لهى سعة هذا العالم بكثير من الرواة وعلى ذلك فالراوي مقبول الرواية. و الله أعلم.

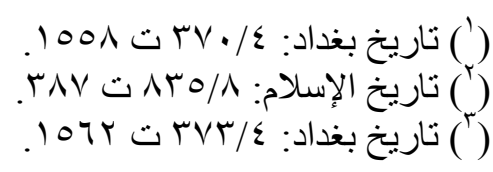




\section{الإقناع بما نقله الخطيب عن شيخه العتيقي}

\section{• . - محمد بن المظفر بن موسى بن عيسى بن محمدل بن عبد الله بن سلمة بن إياس أبو الحسيز}

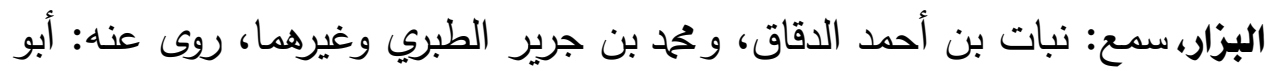
الحسن الدارقطني، وأبو حفص بن شاهين وغيرهما، قال الخطيب: قال العتيقي: كان ثقة مأمونًا حسن الحفظ(')، وقال الخطيب كان حافظًا فهمًا صادقًا مكثرًا (؟)، وقال الأزهري: توفى سنة تسع وسبعين وثلاث مائة(؟)، وقال البرقاني: كتب الدارقطني ألوانًا عن ابن المظفر ، وقال السلمي: سألت الدارقطني عن ابن المظفر فقال: ثقة ونة

مأمون قلت: يقال إنه يميل إلى التشيع قال قليلًا بقدر ما لا يضر إن شاء اللهاء. وقال الخطيب: رأيت الدارقطني يعظم ابن المظفر ويجله(*)، وقال:ابن أبي الفوارس كان ححم بن المظفر ثقة أمينًا مأمونًا حسن الحفظ، وانتهى إليه الحديث وحفظه وعلمه، وكان قديمًا ينتقي على الثيوخ، وكان متقدمًا عندهم(")، وقال القاضي: ححمد بن عمر الداودي رأيت الدارقطني يعظم ابن المظفر ويجله ولا يسند بحضرته(l)، وقال الذهبي: جمع وصنف(^)، وقال الذهبي: ثقة حجة معروف إلا أن أن أبا الوليد الباجي قال: فيه تشيع ظاهر(9)، وقال أبو نعيم: حافظ مأمون، وقال القاضي أبو الوليد الباجي: ابن المظفر حافظ فيه تشيع ظاهر (·)، وقال ابن العماد: كان من أعيان الحفاظ، وقال ابن ناصر الدين: كان محدث العراق حافظًا ثقة نبيلً

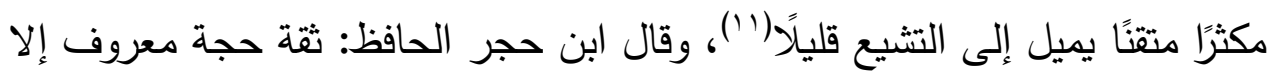

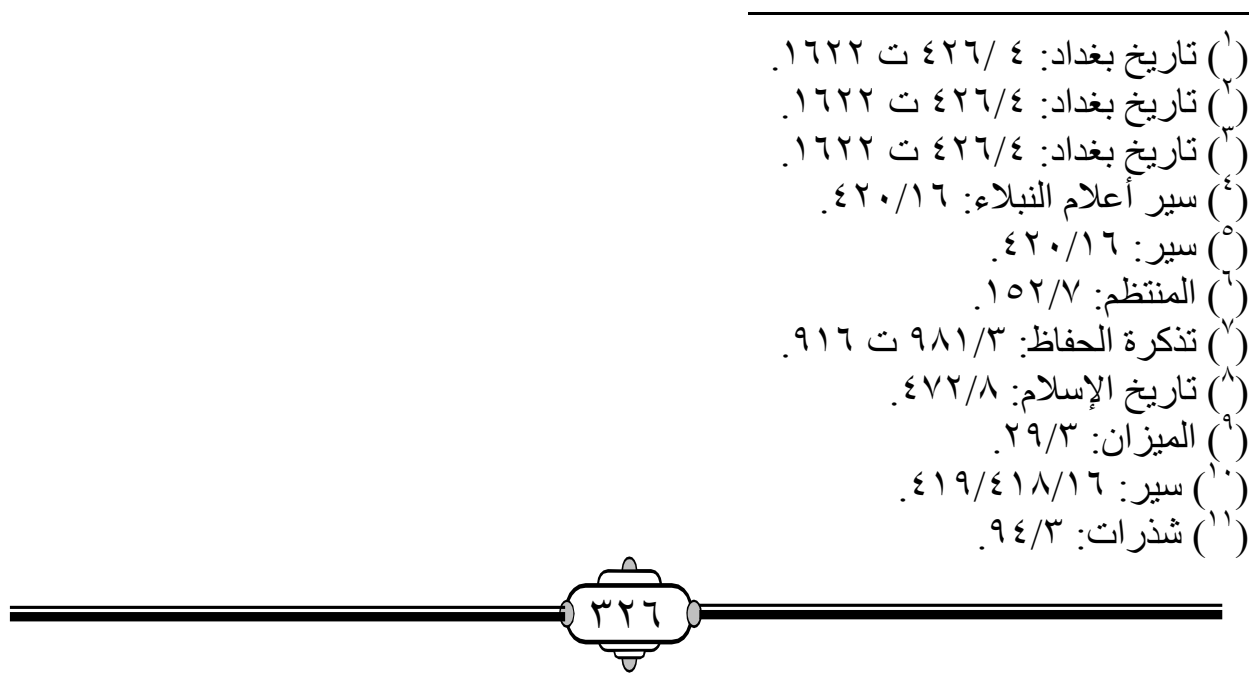




\section{الإقناع بما نقله الخطيب عن شيخه العتيقي}

أن أبا الوليد الباجي قال فيه تشيع ظاهر قال: وما كان ينبغي للذهبي أن يذكره بهذا القدح البارد وما أدري لم يقلد الباجي في قوم لم يحط الباجي بأحوالهم علمًا كما ينبغي ولنذكر ترجمته ليظهر مقداره ثم ذكر ترجمته وأقوال أهل العلم السابقة فيه (').

\section{فلاصة مال الراوب!:}

من خلال كلام الأئمة السابقين في الراوي نجدهم قد اجتمعوا على توثيقه وقبوله، وما كان فيه من تشيع قليل لا يضر، ولم نجد للتشيع فيه دعوة من خلال كلام العلماء فانتفت عنه صفة التثيع المضر ، ومن ثم نقل الخطيب قول العتيقي بصيغة من صيغ الأداء بقال ووافق قوله قول الأئمة دون أن يتطرق إلى قضية التشيع عنده، وكأنه رأى عدم دعوته لذلك، فالراوي بمجمل القول مقبول الرواية والله أعلم.

ا Y- - محمد بن النضر بن محمد بن سعيد بن رزين بن عثمان بن المضيرة أبو الحسين النخاس (r)

الموصلي، حدث عن: أبي يعلى الموصلي، وعبد الله بن محمد بن زياد النيسابوري وغيرهما، روى عنه: أبو بكر الدقاق، وأبو القاسم الأزهري وغيرهما، قال الخطيب: قال العتيقي: وفيه تساهل(r)، وقال الخطيب: سمعت أبا بكر البرقاني وحدثا عن أبي الحسين النخاس فقال: كان واهيًا، وسمعته مرة أخرى يقول ليس بحجة، وسمعته

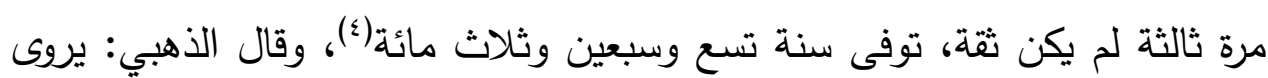
معجم أبي يعلى عنه(ْ)، ونقل الذهبي قول البرقاني، والعتيقي (־)، ونقل ابن العماد

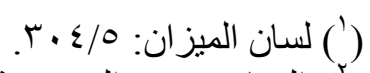

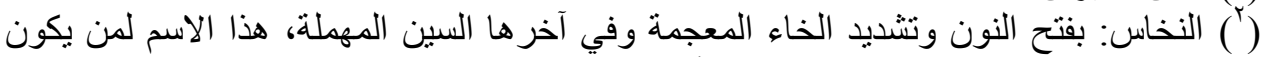

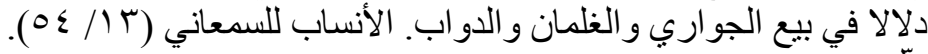

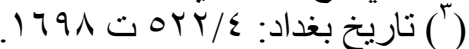

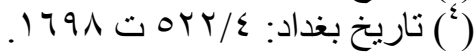

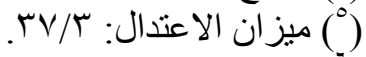

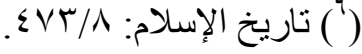


قول البرقاني والعتيقي (').

\section{فاصة صال الراوبي:}

تساهل الراوي الذي نقله الخطيب عن العتيقي جاء بصيغة قال التي هي من صيخ الأداء جاء قول العتيقي عنه موافقًا لقول غيره من العلماء فالراوي غير مقبول الرواية ما إذا انغرد بذلك فإذا وقعت المتابعة من غيره بمثله أو أعلى منه قبل الراوي عودي عئه وإلا كان ضعيفًا غير مقبول الرواية و الله أعلم.

r T - محمد بن يوسف بن محمد أبو بكر العلاف يعرف بابن دوست سمع عبد الله

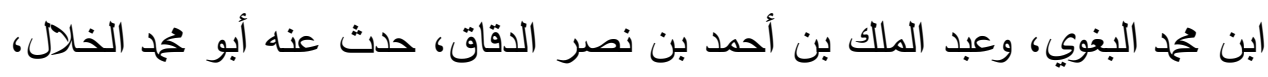

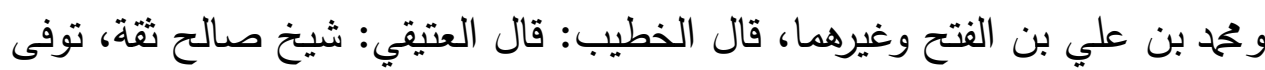
سنة إحدى وثمانين وثلاث مائة(r)، وقال الخطيب كان ثقة(r) وذكر الذهبي قول

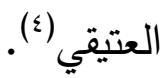

\section{خلاصة مال الراوبي:}

الخطيب نقل عن العتيقي هذا القول بتلك الصيغة ووافق وصرح بذلك في حق الراوي ووافقهما ضدنًا على ذلك التوثيق الإمام الذهبي، فبذلك يكون ذلك الراوي مقبول الرواية و الله أعلم.

بr- محمد بن يحيى بن مهلي أبو عبد الله الجرجاني، الفقيه على مذهب أبي حنيفة، توفى سنة ثمان وتسعين وثلاث مائة، قال الخطيب: قال العتيقي: وكان

فقيهًا عالمًا (ن)

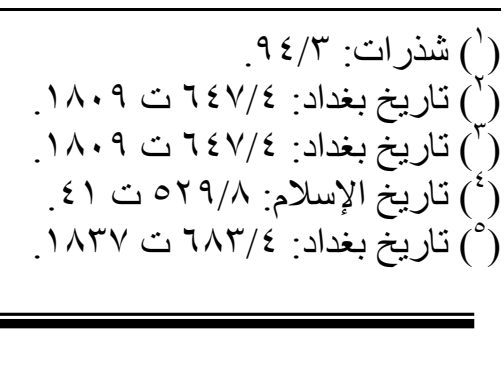




\section{فلاصة مال الراوبي:}

الخطيب نقل عن العتيقي كون هذا الراوي فقيهًا عالمًا وانفرد العتيقي بذلك القول في الراوي فالأولى الاعتماد عليه في قبول الراوي والاحتجاج به و الله أعلم. ع r- أحمد بن إبراهيه بن مهران بن سيسر أبو الفضل البوشنجي(')، حدث عن: سفيان ابن عيينة، وأبي ضمرة أنس بن عياض، روى عنه: وكيع القاضي وحمحان ابن مخلد العطار وغيرهما، قال الخطيب: حدثنيه أحمد بن محمد العتيقي قال ححم بن إبراهيم البوشنجي أبو الفضل بغدادي ليس بقوي يعتبر به(r)، وقال الخطيب: قال

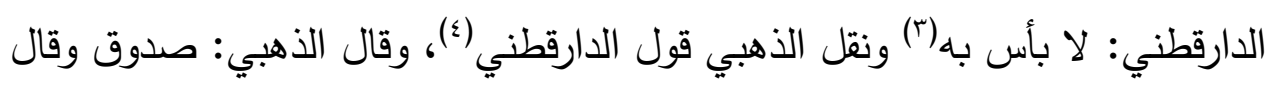
العتيقي عن الدارقطني: ليس بقوي(ن).

\section{فلاصة مال الراوي:}

نقول وبالله التوفيق هذا الراوي يحتاج إلى متابع وعاضد له حتى يقبل، وجاء القول من الخطيب في نقله عن العتيقي ذلك بصيغة التحديث التي هي أرفع أنواع صيغ الأداء و الله أعلم.

ه - - أحمد بن عبيد الله بن عمر بن حمدان أبو عبدالله المعروف بابن الحذايء، حدث عن:

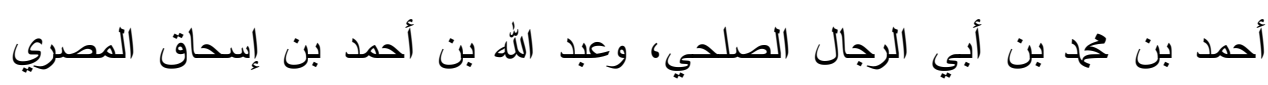
الجوهري وغيرهما، حدث عنه: أحمد بن حمد العتيقي، قال الخطيب: سألت العتيقي

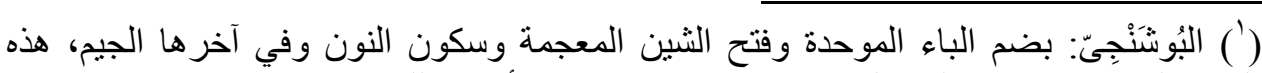

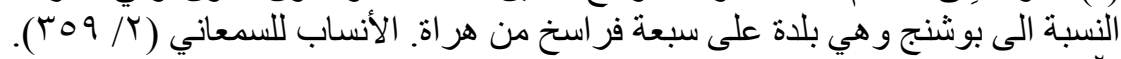

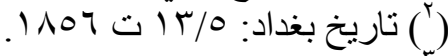

$$
\begin{aligned}
& \text { () (Y) تاريخ بغداد: }
\end{aligned}
$$

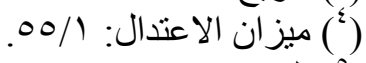

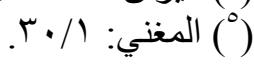


عن أبي الحذاء فقال ثقة ('). خلاصة مال الراوي؟:

سأل الخطيب الإمام العتيقي عن راوٍ معين وهو أحمد بن عبيد الله الحذاء فأجابه بقبول روايته والاحتجاج به وهذا الراوي ممن انفرد بالقول فيه العتيقي دون غيره من العلماء . و الله أعلم.

جr- أحمد بن عمر بن محمد بن خرشيذ قوله أبو علي الأصبهاني سمع حمح ابن منصور الشيعي، وعبد الله بن محمد بن زياد النيسابوري وغيرهما، حدث عنه:

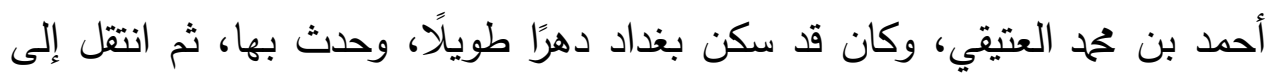
مصر فنزلها وأقام بها حتى مات، قال الخطيب: قال لي العتيقي: سمعت منه ببغداد وتوفى بمر سنة أربع وتسعين وثلاث مائة، وكان ثقة حسن الأصل(؟)، وقال

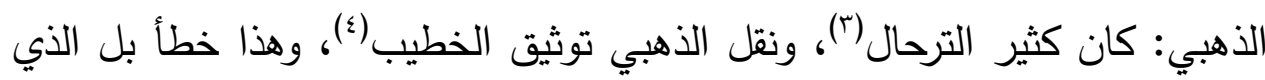
وثته العتيقي وذكر ذلك الخطيب.

\section{فلاصة مال الراوي:}

هذا الراوي موثق من قبل العتيقي بإثبات ذلك عن طريق الخطيب بقوله قال لي ووافق على ذللك التوثيق الضمني الإمام الذهبي، ونقل الذهبي هذا القول على أنه قول الخطيب وهذا وهم من الذهبي، بل القول قول العتيقي كما ذكر الخطيب ذلك الته في تاريخ بغداد، و الله أعلم. TV - أحمد بن علي بن سهلان أبو عبد الله الكسائي(0)، حدث عن: أبي بكر الثافعي،

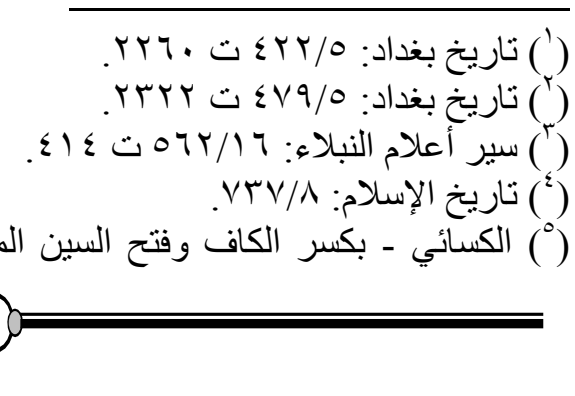




\section{الإقناع بما نقله الخطيب عن شيخه العتيقي}

وأبي شجاح الفضيل بن العباس الهروي وغيرهما، قال الخطيب: قال العتيقي: كان

رجلًا عالمًا وكانت فيه دعابة(')، وقال الخطيب: كتبت عنه وكان صدوقةًا (r).

\section{خلاصة حال الراويى:}

كلام العتيقي الذي نقله الخطيب عنه بصيغة قال: لا يدل على التوثيق الصريح بل يقبل منه على أنه توثيق ضمني، وقبول دون التصريح المباشر لكن جاء قول الخطيب الذي يدل على قبوله بأسلوب التصريح و الله أعلم.

\section{^ץ - أحمد بن الفرج بن منصور بن محمد بن الحجاج بن هاروذ بن حماد بن سعيد ابن الصلت} بن أبان أبو الحسن الفارسي الوراق، سمع: حمد بن مخلد، وأبا العباس بن عقدة وغيرهما، حدث عنه: أبو بكر البرقاني، وأبو القاسم الأزهري وغيرهما، قال الخطيب: سألت أبا الحسن العتيقي هل سمع ابن حجاج شيئًا بغير بغداد ؟ قال: لا، قال: توفى سنة اثنتين وستين وثلاث مائة وكان ثقة كتب الكثير (ז)، وقال الخطيب: كان ثقة، وقال أبو بكر البرقاني: كان يذكر عنه التشيع(ء).

\section{فلاصة مال الراوي:}

نقل الخطيب كلام العتيقي عن هذا الراوي بأسلوب السؤال عنه وتكلم عنه أيضًا، واجتمع قوله مع قول العتيقي بالتوثيق والقبول، وما ذكر غيرهما من وجود التشيع فيه غير ثابت عنه إلا من قول البرقاني ولم نجد له في ذلك دعوة فانتفت عنه صفة التشيع وبقيت فيه صفة التوثيق و الله أعلم.

وץ- أحمد بن محمد بن أبي موسى أبو بكر الهاشمي، سمع إبراهيم بن عبد الصدد

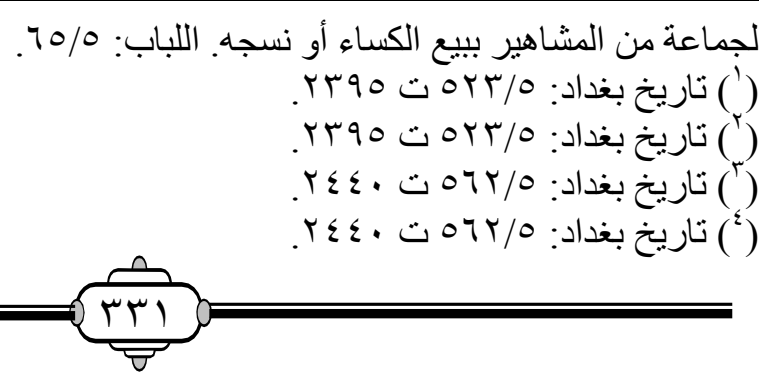




\section{الإقناع بما نقله الخطيب عن شيخه العتيقي}

الهاشمي، وحمد بن جعفر المطيري وغيرهما، حدث عن: أحمد بن تحم العتيقي، وأبي القاسم التتوخي، قال الخطيب: حدثا أحمد بن ححم العتيقي قال سنة تسعين وثلاث مائة فيها توفى القاضي أبو بكر بن أبي موسى وكان ثقة مأمونًا(')، وقال الخطيب: كان ثقة كتب الناس عنه بانتخاب الدارقطني وكان مالكي المذهب وتقلد قضاء المدائن(r)، ونقل الذهبي كلام الخطيب(ّ).

\section{فل1صة مال الراوي:}

الخطيب أدى قول العتيقي بصيغة حدثنا التي هي من أرفع صيغ الأداء عند النقل، ونقل قوله وتكلم عنه أيضًا بالتوثيق فوافق قوله قول شيخه العتيقي ونقل قولهما الذهبي فيكون الراوي مقبول الرواية بإجماع هؤلاء الأئمة الثلاثة و الله أعلم.

• ب- أحمد بن محمدل بن عمران بن موسى بن عروة بن الجراح بن علي بن زيل

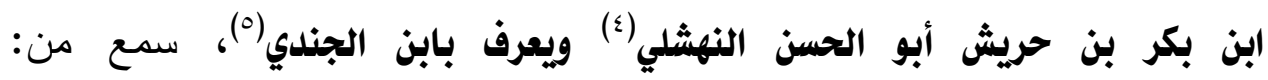
أبي القاسم البغوي، ويحيى بن صاعد وغيرهما، حدث عنه: أبو الحسن العتيقي، وأبو القاسم الأزهري وغيرهما (†). قال الخطيب: قال العتيقي: كان يرمى بالتشيع وكانت له أصول حسان (V)، وقال الذهبي: شيعي)، وقال ابن حجر : وأورد ابن الجوزي في الموضوعات من فضل بلت وان على حديثًا بسند رجاله ثقات إلا الجندي فقال: هذا موضوع ولا يعرف الجندي(9)،

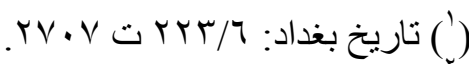

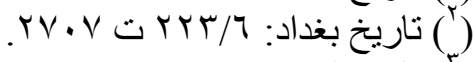

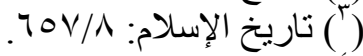

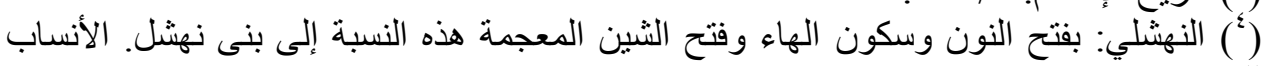

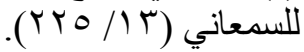
()

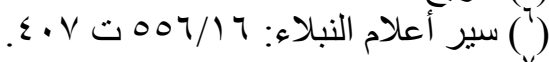

T (") (

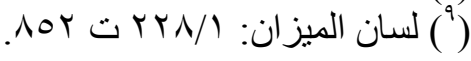




\section{الإقناع بما نقله الخطيب عن شيخه العتيقي}

وقال الخطيب: وكان يضعف في روايته، ويطعن عليه في مذهبه، سألت الأزهري عن ابن الجندي فقال: ليس بشيء، وقال لي الأزهري أيضًا حضرت ابن الجوزي وهو يقرأ عليه ديوان الأنواع الذي سمعه فقال لي أبو عبدالله ابن الأبنوس ليس هذا سماعه، وإنما رأي نسخة على ترجمتها اسم وافق اسمه فادعى ذللك(')، وذكر الذهبي

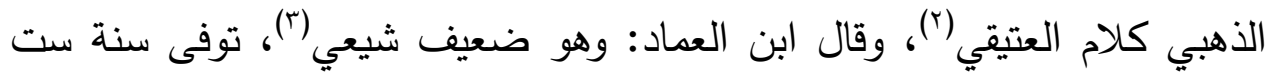

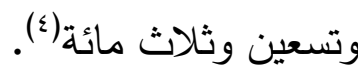

\section{فلاصة مال الراوضي:}

الراوي مثبت عنه التشيع مطعون في روايته وهو بذلك ضعيف إلا ما وجدت له من تلك الأصول الحسان التي ذكرها الإمام العتيقي ومن ثم نقول هذا الراوي ضعيف مالم يتابع في أحاديثه بأقوى منه لا مثله فمثله ضعيف لا يقبل منه بانفراده و الله أعلد.

آب- أحمل بن محمدل بن يعقوب بن عبد الله بن ميلان أبو بكر الوراق الفارسي، حدث عن: عبد الله بن ححم البغوي، ويحيى بن حمح بن صاعد وغيرهما، حدث عنه: أبو القاسم التتوخي، وأحمد بن حمح العتيقي وغيرهما، قال الخطيب: قال العتيقي: وكان ثقة توفى سنة تسعين وثلاث مائة(0)، وقال الخطيب: أخبرنا محمد بن أبي الفوارس قال كان أبو بكر الفارسي ضعيفًا جدًا فيما يدعي عن ابن منيع وكان سماعه في

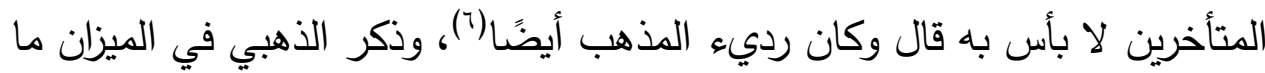
ما سبق من كلام الأئمة(') وكذلك ابن حجر في اللسان(') ونقل الذهبي توثيق

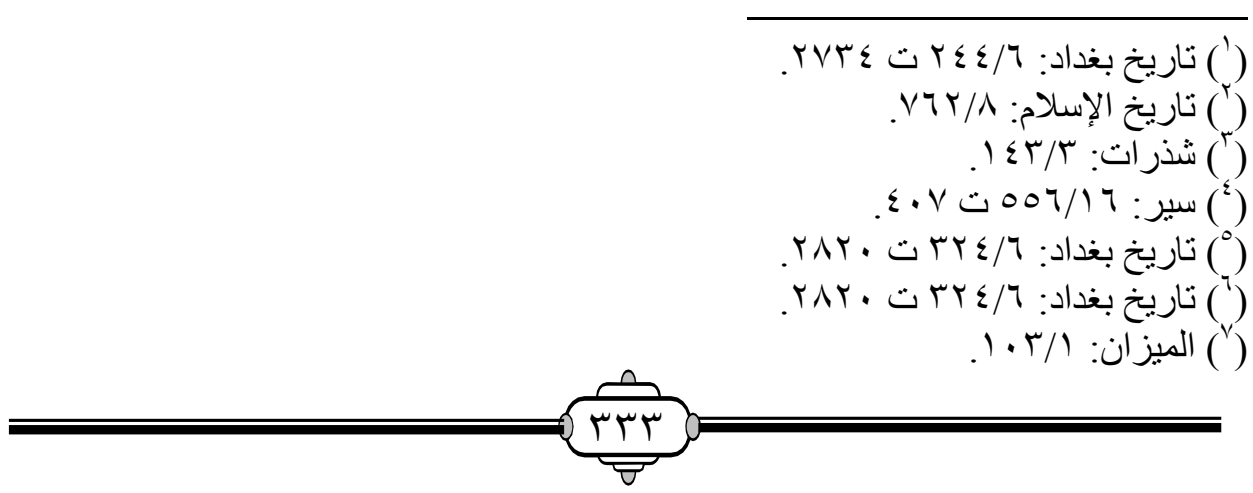


الخطيب(r). قلت: ليس كذلك بل هو توثيق العتيقي.

\section{فاصة مال الراوبي:}

وثقه العتيقي فيما نقله عنه الخطيب بصيغة قال العتيقي: لكن طعنه غيره في روايته عن ابن منيع وقبوله في المتأخرين، وكان رديء المذهب ونقل الذهبي وغيره كلام الأئمة السابقين ووهم الذهبي في إضافة توثيق هذا الراوي للخطيب بل هو هن كلام العتيقي، ومن ثم نقول انغرد العتيقي بتوثيق الراوي وقبوله وذكر الأئمة كلامه وكلام غيره دون التعقيب أو التصحيح لذلك لا نسلم بتوثيق الراوي من قبل العتيقي ولا نضعفه بسبب كلام غيره، أو نتوقف كما توقف غيرهما بل نقول ما كان من رواية ابن منيع ضعيفة لا تقبل وفي غيرها نعرض على غيرهم من الثقات فإن وافقوه قبلت، ولا فهي غير مقبولة و الله أعلم.

Tr- إسماعيل بن سعيد بن إسماعيل بن محمد بن سويد أبو القاسهر المعدل، حدث عن: أبي بكر عبد الله بن حمح بن زياد النيسابوري، وحمح بن الحسن بن دريد وغيرهما، حدث

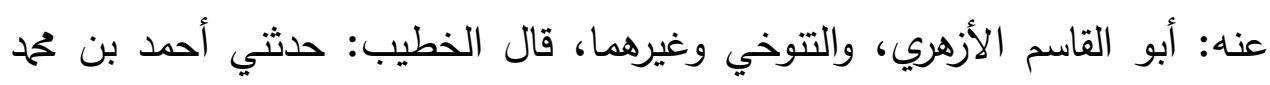
العتيقي قال سنة اثنتين وتسعين وثلاث مائة فيها توفى أبو القاسم بن سويد وكان

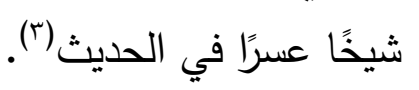

وقال الخطيب: وكان بعض سماعاته صحيحًا في كتب أخيه وبعضها مفسودًا، رأيت إلحاقه لنفسه السماع مع أخيه في جزء عن ابن الأنباري إلحاقًا ظاهرًا بين الفساد، وكذلك رأيته في جزء آخر عن ابن دريد وحدث بالجميع، وحدث أيضًا من آن كتب أخيه لم يكن له فيها سماع قديم ولا ملحق، وحدثني من سمع حمد بن أبي الفوارس ذكره فقال: كان فيه تساهل في الحديث والدين، سألت حمزة بن ححم بن

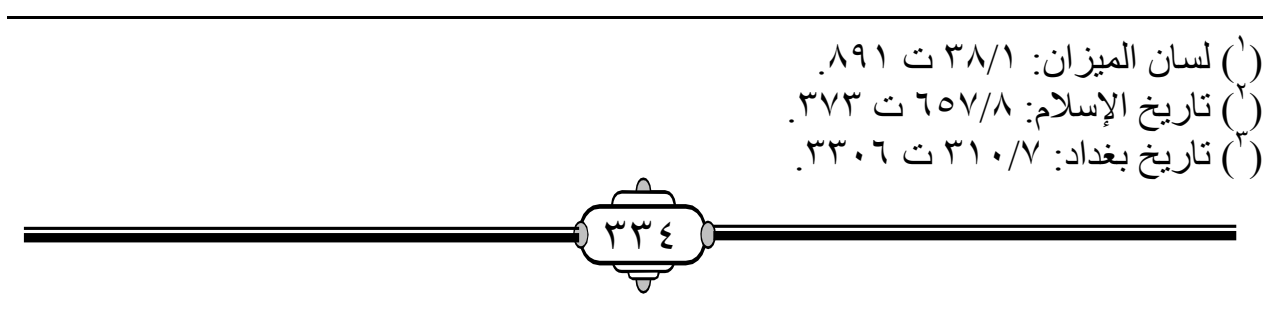




\section{الإقناع بما نقله الخطيب عن شيخه العتيقي}

طاهر عن ابن سويد فقال: ثقة غير أنه كان فيه حمق(')، وقال ابن الفوارس: فيه تساهل في الدين والسماع(؟).

\section{فاصة مال الراوي:}

الخطيب نقل كلام العتيقي بصيغة التحديث والتي مفادها السماع المباشر من شيخه وجاء قوله موافقًا لأغلب أقوال الأئمة من عدم قبول روايته منفردًا ما لم يكن له متابع أو عاضد فإذا وجد المتابع والعاضد له كان مقبول الرواية محتجًا به و الله أعلم.

سب - إدريس بن علي بن إسحاق بن يعقوب بن عبد الله بن رنجويه أبو القاسه المؤدب، حدث

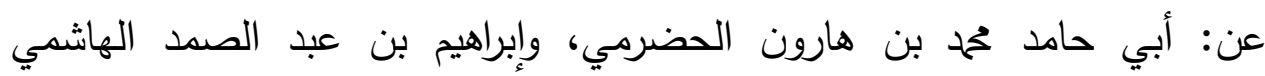
وغيرهما، حدث عنه: أبو القاسم الأزهري، وعلي بن خحمد بن الحسن المالكي

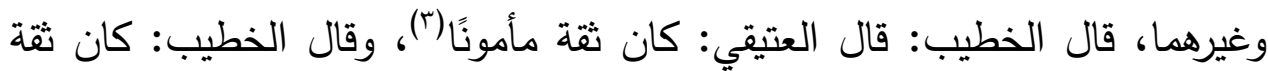

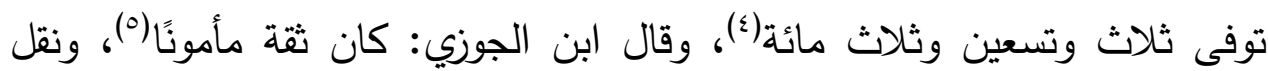
الذهبي توثيق العتيقي (؟).

\section{خلاصة مال الراوي:}

قال الخطيب: قال العتيقي: هكذا نقل قول شيخه العتيقي عن ذلك الراوي بتلك

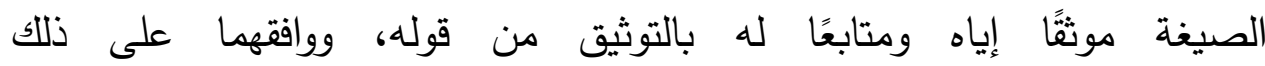
ابن الجوزي صراحة والذهبي ضمنًا فبذلك يكون الراوي من خلال ما تقدم مقبول الرواية محتجًا به و الله أعلم.

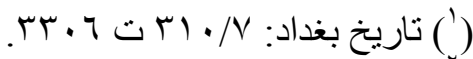

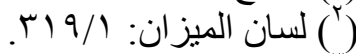

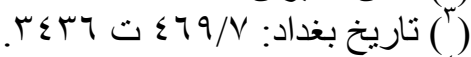

$$
\begin{aligned}
& \text { (") تاريخ بغداد: }
\end{aligned}
$$

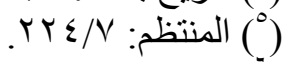

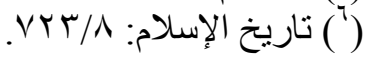


ع ب- جعفر بن محمد بن علي بن الحسين بن إسماعيل بن إبراهيه بن مصعب بن زريق ابن

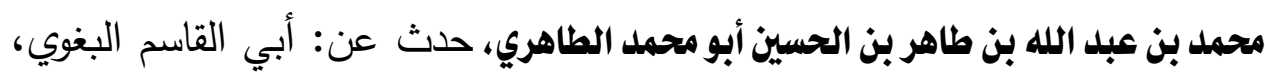

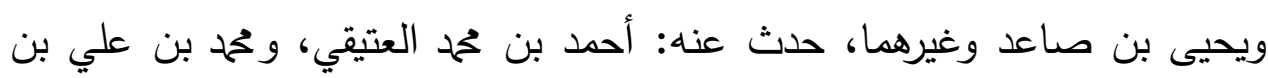
الفتح الحربي وغيرهما، قال الخطيب: سألت العتيقي عن الطاهري فقال: ثقة توفى

سنة ثلاث وثانين وثلاث مائة(')، وقال ابن الأثير : وكان ثقة (r).

\section{فلاصة مال الراوي:}

كثيرًا ما ينقل الخطيب عن شيخه العتيقي بإبراز السؤال له فتكون عنده الإجابة عما سأل، ومن ثم نقول من خلال ما تقدم في ترجمة هذا الراوي أنه نقل عنه التوثيق ووافقه على ذلك ابن الأثير فالراوي مقبول الراوية. والله أعلم.

هب- الحسن بن جعفر بن محمد بن الوضاح بن جعفر بن بشير بن عطاء بن دينار

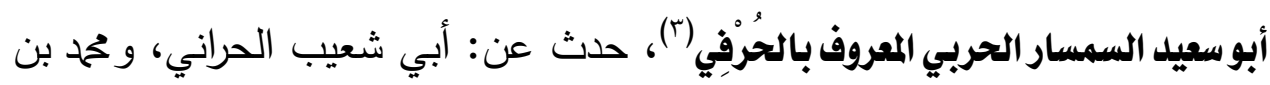
يحيى المروزي وغيرهما، حدث عنه: ححم بن علي الوراق، وأبو القاسم الأزهري وغيرهما، قال الخطيب: حدثني أحمد بن ححم العتيقي قال سنة ست وسبعين وثلاث مائة توفى أبو سعيد الحرفي السمسار وكان فيه تساهل(())، وذكر ابن العماد الحنبلي الحنبلي قول العتيقي(ْ) وكل من ترجم له فيما وقفت عليه من كتب التراجم لـ يتناول يتناول هذا الراوي بجرح أو تعديل(†)، ونقل الذهبي قول العتيقي(') ونقل ابن حجر

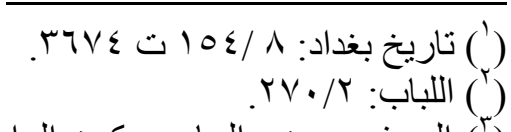

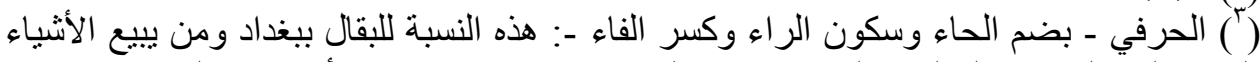

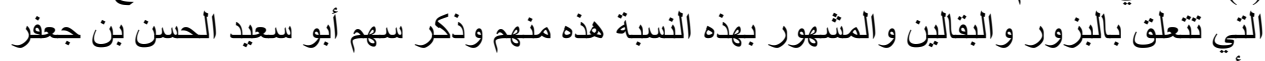

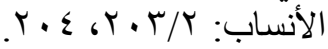

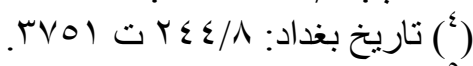

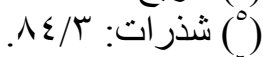

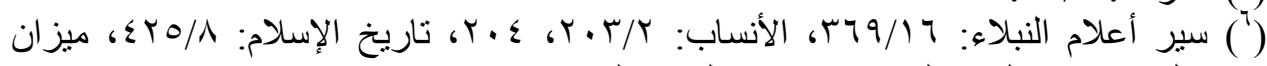

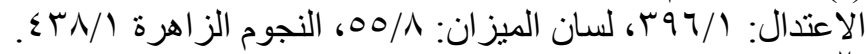
(1)

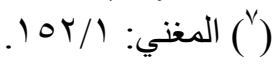




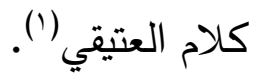

\section{فلاصة مال الراوي:}

الإمام العتيقي حدث الخطيب عن هذا الراوي وأعطاه حقه فيما نقل عنه ولم يذكره بقية العلماء بجرح أو تعديل، ولم يعقب على قول العتيقي الذي نقله جملة دن العلماء الأفذاذ في كتبهم فالظاهر أنهم توقفوا فيه لكن الظاهر لنا أن هذا الراوي ضعيف لا يقبل بانغراد، فإذا توبع بغيره أقوى منه قبل وإلا كان ضعيفًا مردودًا غير مقبول و الله أعلم.

جس- الحسن بن الحسين بن علي بن العباس بن إسماعيل بن أبي سهل بن نوبخت

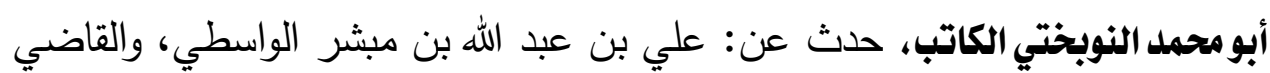
المحاملي وكان سماعه صحيحًا، حدث عن: أبي بكر البرقاني والأزهري وغيرهما، قال الخطيب: حدثني أحمد بن ححمد العتيقي قال سنة اثنتين وأربع مائة فيها توفى أبو حمد الحسن النوبختي (r)، وكان ثقة في الحديث ويذهب إلى الاعتزال (). وقال الخطيب: قال لي الأزهري كان النوبختي رافضيًا رديء المذهب، وقال: سألت البرقاني فقال: كان معتزليًا وكان يتشيع إلا أنه تبين أنه صدوق(أ)، وقياء السمعاني: من أهل بغداد كان معتزليًا رافضيًا رديء المذهب إلا أنه صدوق صحيح السماع(0) ونقل ابن الأثير كلام السمعاني(ج)، وذكر الذهبي كلام الخطيب كان

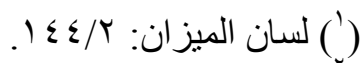

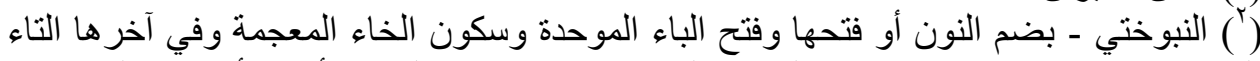

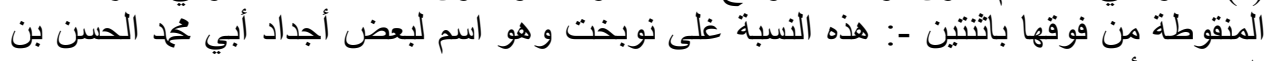

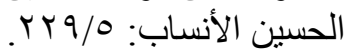

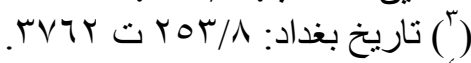

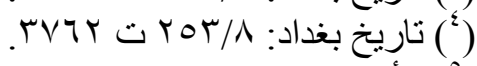
( ) ( ) (الأنساب: (1) اللباب:

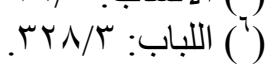




\section{الإقناع بما نقله الخطيب عن شيخه العتيقي}

سماعه صحيحًا وذكر قول الأزهري(') ونقل ابن حجر كلام العتيقي والبرقاني(').

\section{فاصة مال الراوي:}

نقل الخطيب كلام العتيقي بصيغة حثثنا والتي هي أرفع ألفاظ الأداء عند التحمل، ووثقه العتيقي في ذلك النقل لكن طعنه بالاعتزال، وطعنه غيره بالرفض، والآخر بالتشيع، كل ذلك يضعف الراوي إذا كان داعيًا إلى ما سبق فكل ما فيه دعوة إلى ذلك فترد روايته بذللك، ومن غير ذللك فهو مقبول الرواية يقول العتيقي والبرقاني والسمعاني والخطيب وابن الأثير صراحة وغيرهم ضمنًا فالراوي يقبل متى خلت روايته من صفة التشيع والرفض والاعتزال، وما عدا ذلك يكون الراوي فيها مقبول الرواية و الله أعلم.

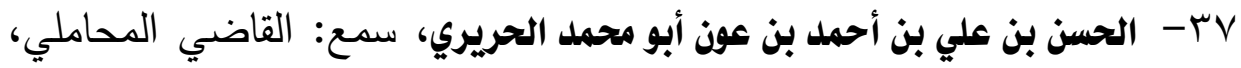
وعثمان بن عبد ربه البزار وغيرهما، حدث عنه: أحمد بن عحم العتيقي، قال الخطيب: قال لي العتيقي: توفى ابن عون سنة تسع وثمانين وثلاث مائة وكان

ثقة(؟)، ونقل الذهبي توثيق العتيقي (ء).

\section{فل1صة مال الراوي:}

انفرد العتيقي بتوثيق الراوي فيما نقل عنه ذلك الخطيب بصيغة قال لي العتيقي ونقل الذهبي في الراوي توثيق العتيقي فهو موافق على ذلك ضمنيًا وعلى ذلك فهو مقبول الرواية و الله أعلم.

^ץ- الحسن بن محمد بن بشران أبو محمد روى عن القاضي المحاملي ومحمد ابن مخلد اللدوري، حدث عنه: أحمد بن محمد العتيقي وسألته عنه هو قرابة بني بشران إنى

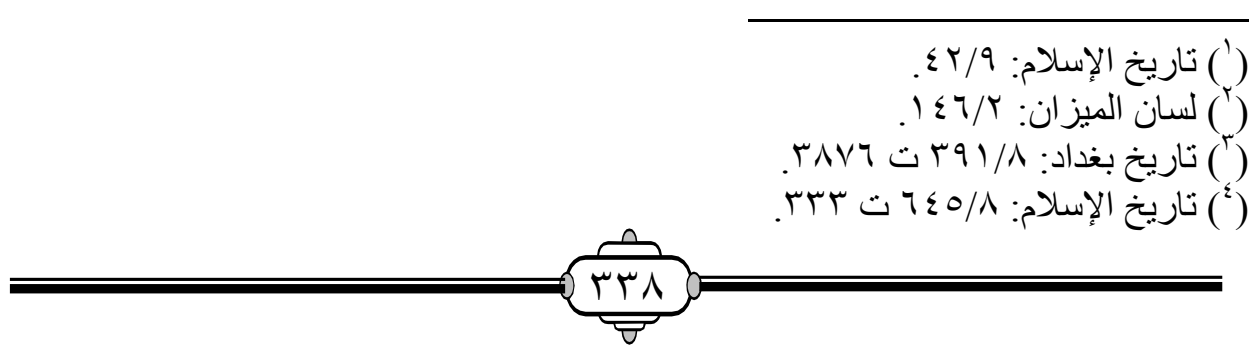




\section{الإقناع بما نقله الخطيب عن شيخه العتيقي}

كان ثقة(')، ونقل ححمد بن عبد الغني البغدادي أبو بكر كلام الخطيب(؟).

\section{فلاصة هال الراوي:}

سال الخطيب الإمام العتيقي عن هذا الراوي فأجابه بكونه عنده موثق، وانفرد العتيقي بذلك القول في الراوي، ونقله عنه محمد بن عبد الغني البغدادي وكأنه موافق على ذلك التوثيق الضمني للراوي، وعلى ذلك يكون الراوي مقبول الرواية محتجا به، و الله أعلم.

q"- الحسين بن جعفر بن محمد أبو القاسه الواعظ المعروف بالوزان، سمع: أبا القاسم

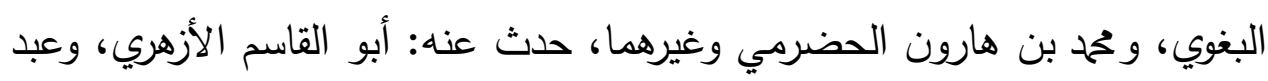
العزيز الأزجي وغيرهما، قال الخطيب: قال العتيقي: وكان ثقة أمينًا() وقال الخطيب: قال الأزهري: وكان ثقة ستيرًا صالحًاء)؛ وذكره الذهبي دون جرح ولائي تعديل(0)، وقال الخطيب: توفى سنة ست وسبعين وثلاث مائة(؟).

\section{خلاصة مال الراوي؟:}

نقل الخطيب توثيق هذا الراوي عن الإمام العتيقي بقوله قال العتيقي: ووافقه على ذللك التوثيق الإمام الأزهري ولم يذكر فيه الذهبي كلامًا وعلى ذلك فالاعتماد على الإمى قول العتيقي والأزهري في توثيق الراوي وقبوله و الله أعلم.

• ـ- الحسين بن علي بن سهل بن وهب أبو القاسه السمسار، حدث عن: أحمد ابن حمح بن مسعدة الفزاري، وأحمد بن علي الجوزجاني وغيرهما، حدث عنه: أحمد بن

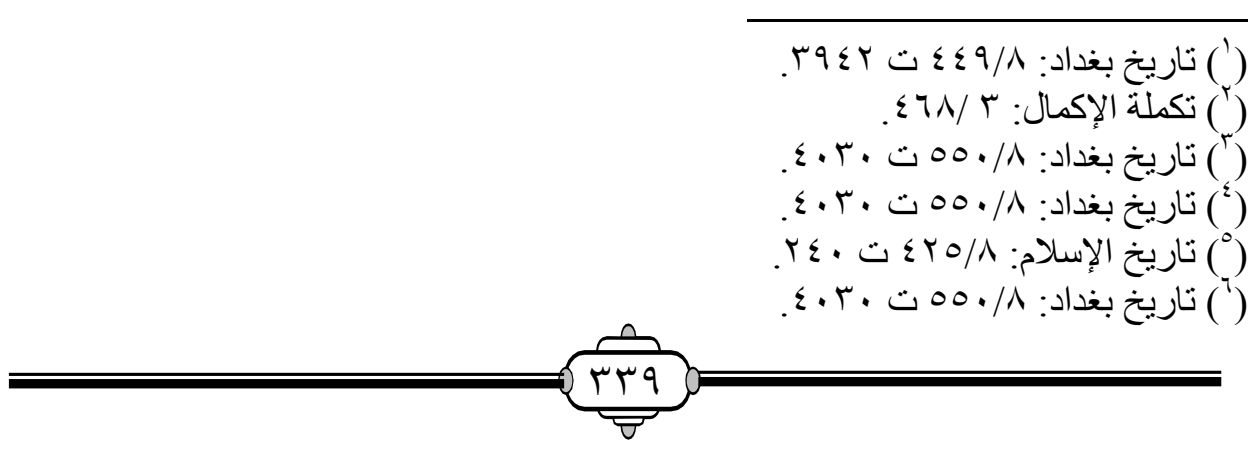




\section{الإقناع بما نقله الخطيب عن شيخه العتيقي}

بن تحمد العتيقي، قال الخطيب: سألت عنه العتيقي فقال: كان ثقة(').

\section{فاصة مال الراوبي:}

انفرد الإمام العتيقي بتوثيق هذا الرأي من خلال السؤال عنه من قبل الخطيب البغدادي فالأخذ والاعتماد على قبوله أرجح وأولى من تركه و الله أعلم.

إ - الحسيز بن محمل بن خلف أبو عبد الله بن الفراء أحلد الشهود المعدلين، حدث عن:

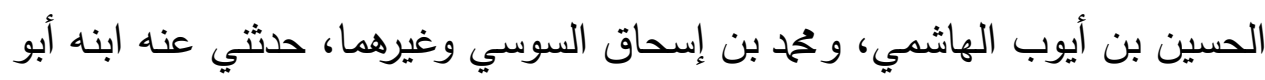

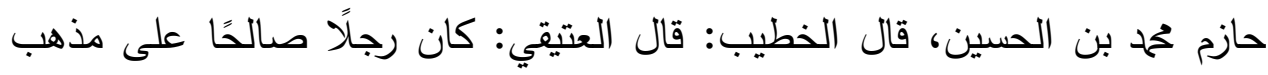
أبي حنيفة توفى سنة تسعين وثلاث مائة(؟)، وقال ابن تغري بردي: كان إمامًا فقيهًا

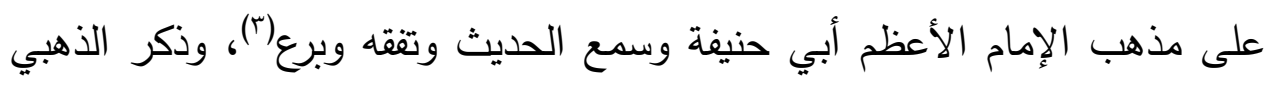

قول العتيقي (ء).

\section{فاصة مال الراوبي:}

لم يُنْقل عن أحد من الأئمة تضعيف الراوي لكن جاء في مضمون كلام العتيقي

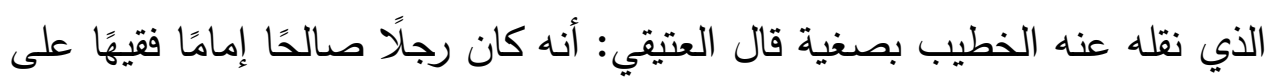
مذهب أبي حنيفة ووافقه في ذلك ابن تغري بردي بقوله والفقه مؤدي إلى قبول الراوي مع الصلاح الذي ذكره العتيقي و الله أعلم.

r؟- داود بن سليمان بن داود بن محمد بن رباح أبو الحسن البزار، سمع: حمح

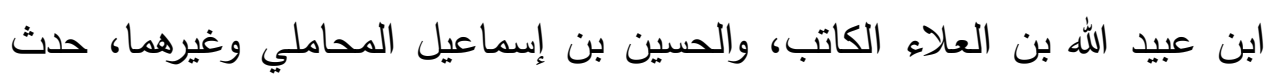
عنه: أحمد بن تحمد العتيقي، وعلي بن المحسن التتوخي وغيرهما، قال الخطيب:

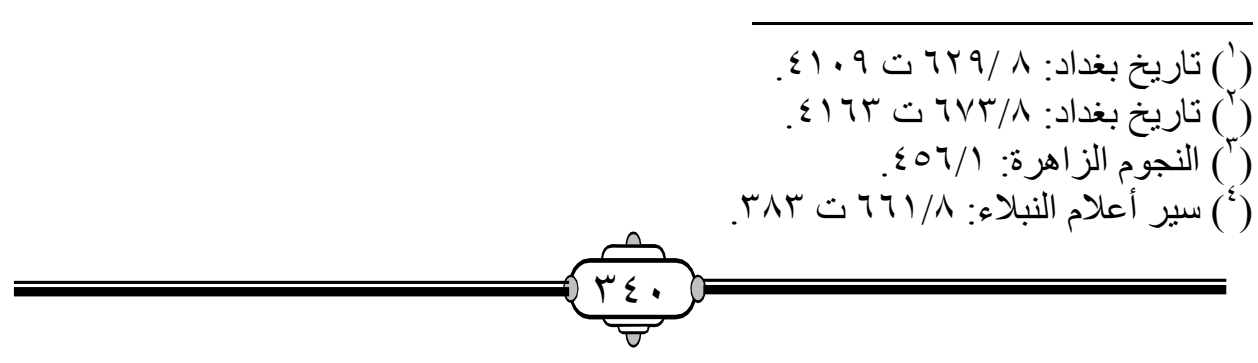




\section{الإقناع بما نقله الخطيب عن شيخه العتيقي}

سألت العتيقي عنه فقال كان شيخًا نبيلًا ثقة(')، وقال: سألت عنه ححمد بن علي بن الفتح فقال: كان ثقة توفى سنة خمس وثمانين وثلاث مائة(r) وذكر الذهبي توثيق

العتيقي (r)، وذكر ابن الجوزي كلام العتيقي(ء).

\section{خلاصة حال الراوي:}

حال هذا الراوي كان عن طريق سؤال الخطيب البغدادي لشيخه العتيقي فكانت الإجابة منه بالتوثيق لله ووافقه على ذللك تحمد بن علي بن الفتح، ونقل قول العتيقي الذهبي وابن الجوزي فكان ذلك توثيقًا ضمنيًا ينضم إلى توثيق العتيقي وابن الفتح فيكون بذللك التوثيق الصريح والضمني مقبول الرواية. و الله أعلم.

بـ- سهل بن أحمد بن عبل الله بن سهل أبو محمد الديباجي(م)، حدث عن: أبي خليفة الفضل بن الحباب الجمحي، وأبي بكر بن الأنباري وغيرهما، حدث عنه: الأزهري، والعتيقي وغيرهما، قال الخطيب: قال العتيقي: كان رافضيًا ولم يكن في الحديث بذاك(")، وقال الخطيب: سألت الأزهري عن سهل الديباجي فقال: كان كذابًا كذابًا رافضيًا زنديقًا، وقال الأزهري: لـ يكن له أصل يعتمد عليه ولا كتاب صحيح قال: ورأيت في داره على الحائط مكتوب لعن أبي بكر وعمر وباقي الصحابة العشرة سوى علي(Y)، وقال: ابن أبي الفوارس كان سهل الديباجي آية ونكالًا في الرواية كان كان رافضيًا غاليًا فيه وكتبنا عنه كتاب محهد بن حمه بن الأشعث لأهل البيت مرفوع

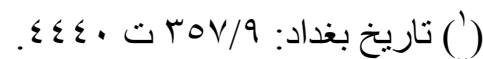

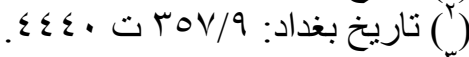

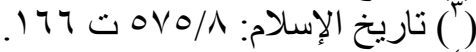

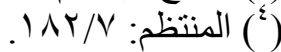

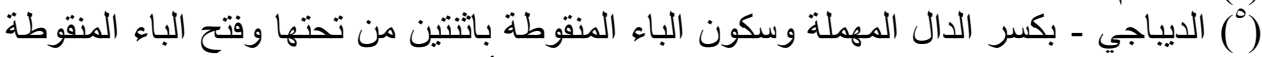

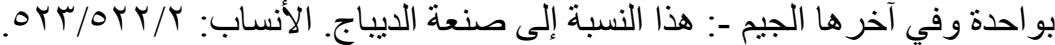

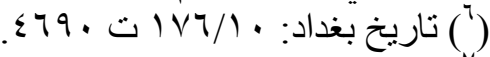

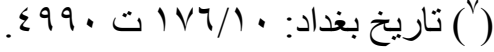




\section{الإقناع بما نقله الخطيب عن شيخه العتيقي}

ولم يكن له أصل معتمد عليه ولا كتاب صحيح توفى سنة ثمانين وثلاث مائة(')،

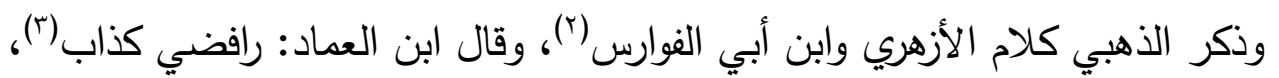
كذاب()، وقال الذهبي: ردى بالأخوين الرفض والكذب(؟)، وذكر ابن حجر كلام الذهبي والأزهري وابن أبي الفوارس والعتيقي(0) وذكر السمعاني كلام الأئمة السابقين (־). (ال)

\section{فلاصة مال الراوي:}

هذا الراوي لا يقبل ولا يعتبر به من خلال كلام جميع الأئمة وبذلك يكون العتيقي قد أحسن فيه الكلام الذي نقله الخطيب عنه بصيغة قال العتيقي: فهو درود الرواية لا يتابع على حديثه و الله أعلم.

ع ـ - صالح بن محمل بن المباركك بن إسماعيل أبو طاهر المقرئ المؤدب، حدث عن: أبي ذر أحمد بن ححم الباغندي، وأبي بكر بن مجاهد المقرئ، حدث عنه: عبدالعزيز

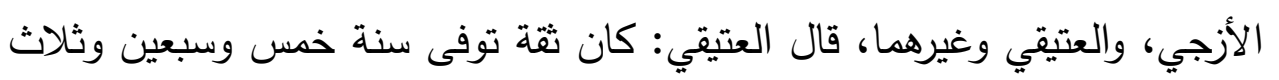

مائة (v)

\section{فلاصة مال الراوي؟:}

انغرد العتيقي بقوله في هذا الراوي وذكر قوله الخطيب في تاريخه بقوله قال العتيقي: فقبوله بالاعتماد على قول العتيقي أحرى وأولى وهو ممن انغرد به العتيقي في الكلام على الراوي، و الله أعلم.

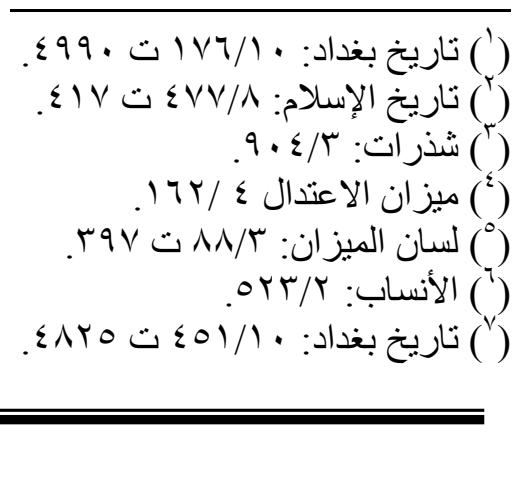




\section{الإقناع بما نقله الخطيب عن شيخه العتيقي}

0ـ- الطيب بن يمن بن عبد الله أبو القاسه مولى المعتضل بالله، سمع: عبد الله

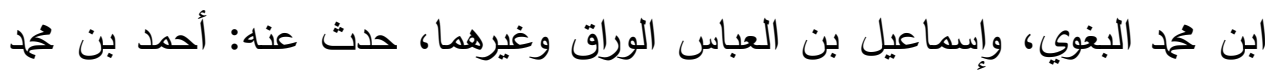
العتيقي، والحسن بن علي الجوهري وغيرهما، قال الخطيب: سمعت العتيقي ذكره فقال: كان ثقة صحيح الأصول توفى سنة أربع وثمانين وثلاث مائة(')، وقال الذهبي: وهو ثقة(؟)، وذكر ابن الجوزي قول العتيقي(ץ).

\section{خلاصة مال الراوي:}

وافق الذهبي قول العتيقي الذي ذكره الخطيب بصيغة السماع من شيخه، ونقل قوله ابن الجوزي في المنتظم، وبذلك يكون الراوي مقبولًا اعتمادًا على قول العتيقي والذهبي صراحة والمنتظم نقلًا و الله أعلم.

T؟ - عبد الله بن أحمد بن محمد بن عبد الله أبو الحسيز المقرئ الأصبهاني، حدث عن: محمد بن عمر بن حفص، و ححمد بن بكر بن داسة وغيرهما، حدث عنه: البرقاني، وعبد الملك بن محمد الرزاز وذكر لنا أنه كان عابدًا، قال الخطيب: سألت العتيقي عنه بنه

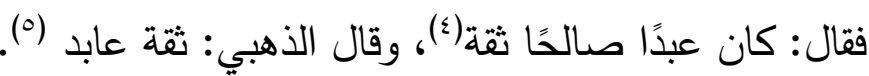

\section{فلاصة مال الراوي:}

الخطيب سأل العتيقي عن عبد الله بن أحمد المقرئ فوثقه ووافقه الذهبي في التاريخ، فيقبل الراوي لقولهما فيه بالتوثيق و الله أعلم. §V ابن جعفر المنادى، وإسماعيل بن عحم الصفار حدثني عنه العتيقي وسألته عنه فقال

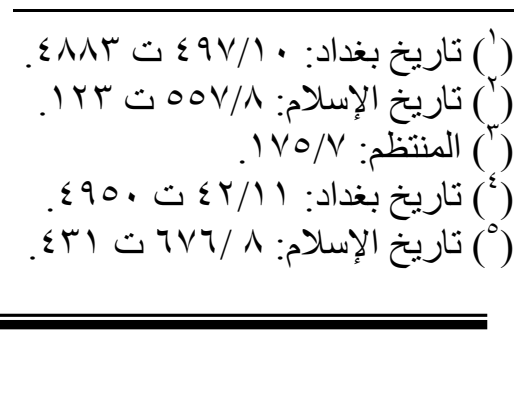


شيخ صالح لا بأس به(1).

\section{خلاصة مال الراوي:}

انفرد العتيقي بالقول في هذا الراوي والذي نقله عنه الخطب البغدادي بقوله سألته عنه فقال: شيخ صالح لا بأس به، والتي تعني قبوله والاحتجاج به وإن كان دون غيره في القوة ممن قيل عنه ثقة وغيرهما، من الألفاظ الدالة على القبول بخلاف هنا والتي تفيد التحسين، و الله أعلم.

^ـ - عبد الله بن الحسين بن عبد الله أبو محمد الخلال يعرف بابن الشيلماني(؟)، سمع:

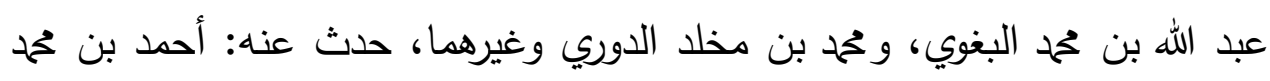
العتيقي، وعبد العزيز الأزجي، قال الخطيب: سألت العتيقي عن الخلال فقال: كان

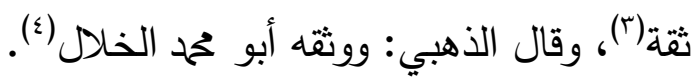

\section{خلاصة مال الراوي؟:}

انفرد العتيقي بتوثيق هذا الراوي عن طريق تلميذه الخطيب البغدادي حين سأله عنه، ووافق على ذلك أبو عحم الخلال فيما نقله الذهبي عنه، فيكون الراوي مقبول الرواية و الله أعلم. و ؤقى

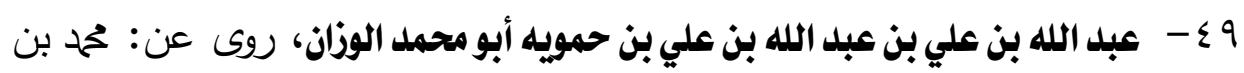

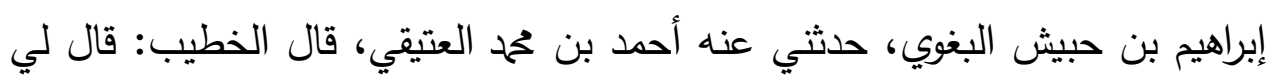
العتيقي: كان هذا الشيخ يتفقه على مذهب أبي حنيفة وكان أبو محمد بن الأكفاني

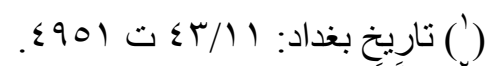

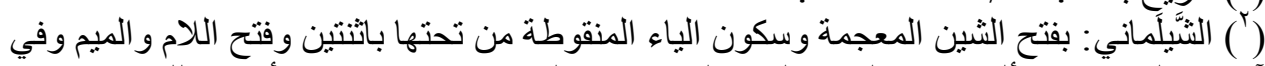

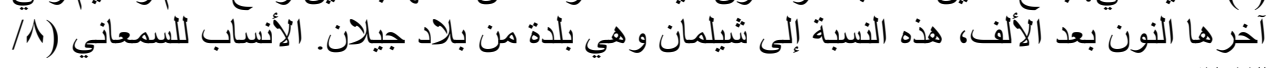

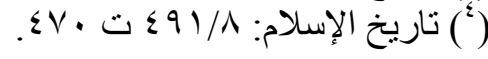




\section{الإقناع بما نقله الخطيب عن شيخه العتيقي}

يجله وكان سماعه صحيحًا وكان عنده شيء يسير من الحديث ('). خلاصة مال الراوي؟:

الراوي متفقهًا سماعه صحيحًا كان عنده شيء يسير من الحديث كل هذه الألفاظ التي نقلها الخطيب عن شيخه العتيقي بصيغة قال تؤيد قبوله والاحتجاج به والله أعلم.

• - - عبيد الله بن أحمد بن يعقوب بن أحمد بن عبيد الله أبو الحسن المقرئ يعرف بابن

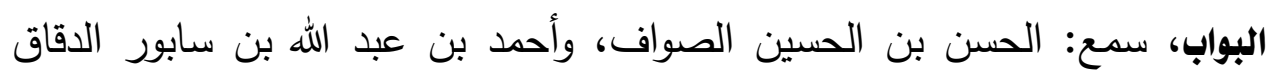
وغيرهما، حدث عنه: الحسن بن تحم الخلال، والعتيقي وغيرهما، قال الخطيب: قال العتيقي: كان ثقة مأمونًا توفى سنة ست وسبعين وثلاث مائة(؟)، وقال الخطيب:

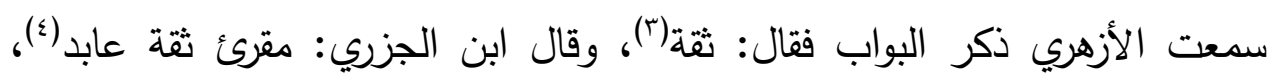

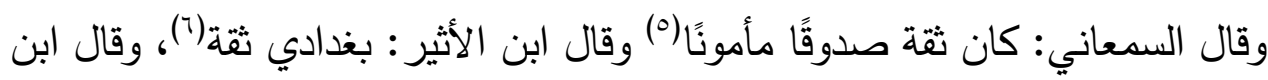

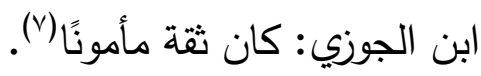

\section{خلاصة مال الراوي؟:}

قول الخطيب في هذا الراوي قال العتيقي: كان ثقة وموافقة الأزهري وابن الجزري والسمعاني وابن الأثير وابن الجوزي كفيل على الاحتجاج به وقبوله و الله أعلم.

10- عبيد الله بن خليفة بن شداد أبو أحمد البلدي، حدث عن: هارون بن السكين

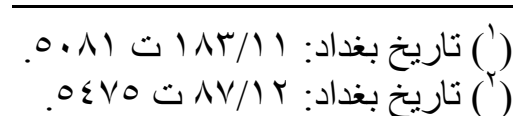

() (r) تاريخ بغداد:

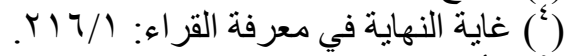

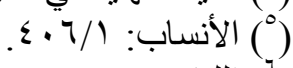

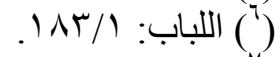

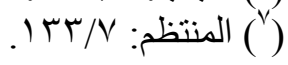




\section{الإقناع بما نقله الخطيب عن شيخه العتيقي}

البلدي، حدث عنه: الأزهري، والعتيقي، قال الخطيب: سألت العتيقي عنه فقال: ثقة توفى سنة تسع وثمانين وثلاث مائة(')، وقال الخطيب: كان صدوقًا(Y)، وقال ابن الن الجوزي: كان صدوقًا ثقة (؟).

\section{فلاصة مال الراوي:}

وثقه العتيقي عن طريق سؤال الخطيب البغدادي عن ذلك الراوي، وجمع ابن الجوزي بين عبارتين تدلان على القبول بدرجة الصحيح، وكان قبول الخطيب له في حد الحديث الحسن فالراوي بمجمل أقوال أهل العلم مقبول الرواية والله أعلم.

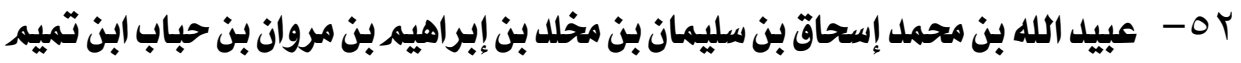

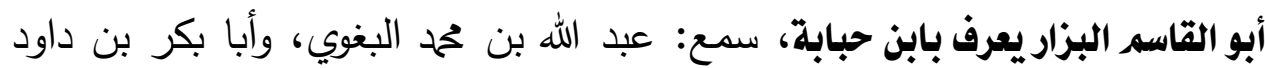
ومن بعدها، حدث عنه: الأزهري، والعتيقي وغيرهما، قال الخطيب: قال العتيقي:

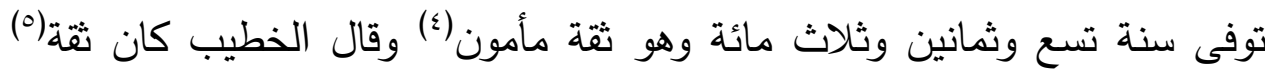
وقال السمعاني محدث بغداد أحد الموصوفين بالصدق والديانة والأمانة(؟) وقال ابن الجوزي وكان صدوقًا ثقة(Y) وذكر ابن الأثير كلام السمعاني(^) ولم يذكر فيه الذهبي الذهبي شينًا(9) ونعته الذهبي بالثيخ المسند العالم الثقة وذكر توثيق الخطيب

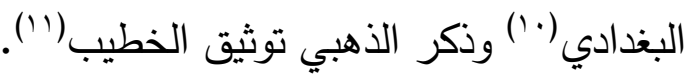

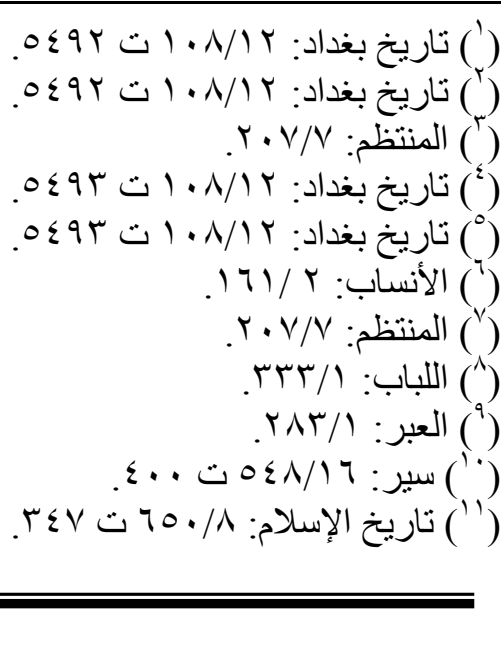




\section{فلاصة هال الراوي:}

الراوي مقبول الرواية بسبب قول العتيقي الذي نقله الخطيب البغدادي عنه بقوله قال العتيقي، وبقول جميع العلماء الذين تكلموا على الراوي سواء بالقبول الصريح أو لوبهي الضمني، بنقل أقوال أهل العلم دون الاعتراض أو التعقيب على ما نقلوا والله أعلم.

به - عبيدالله بن محمدل بن أحمد بن محمدل بن علي بن مهران أبو أحمد بن أبي سله الفرضي

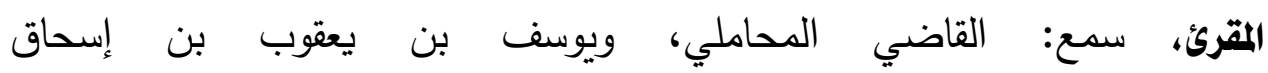
ابن البهلول، حدث عنه: الخلال، والأزهري، وجماعة، قال الخطيب: سمعت العتيقي ذكره فقال ثقة مأدون ما رأينا مثله في معناه(')، وقال الخطيب: كان ثقة صدوقًا دينًا دينًا وورعًا وقال: سمعت الأزهري ذكره فقال: كان إمامًا من الأئمة(؟)، وقال السمعاني: من أهل بغداد كان إمامًا فاضلًا ثقة مأمومًا من الأئمة الورعين وكان الأنسان رأسًا في القراءات(؟)، وقال الذهبي: أحد الأعلام معرفة القراء الكبار(گ)، وقال الخطيب: توفى سنة ست وأربع مائة(ْ)، وذكر ابن العماد كلام الخطيب والعتيقي وقال

والأزهري(') ابن الجزري في غاية النهاية: إمام كبير ثقة ورع أخذ القراءة عرضًا وسماعًا(V)، وقال منصور الفقيه: لم أر في الشيوخ من يعلم لله غير أبي أحمد الفرضي اجتمعت فيه أدوات من علم وقرآن وإسناد وحالة من الدنيا متسعة وكان مع ذللك أورع الخلق

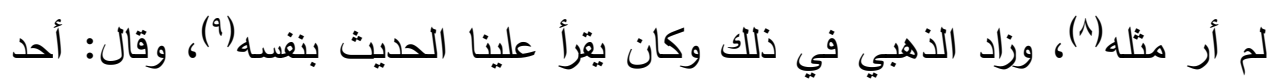

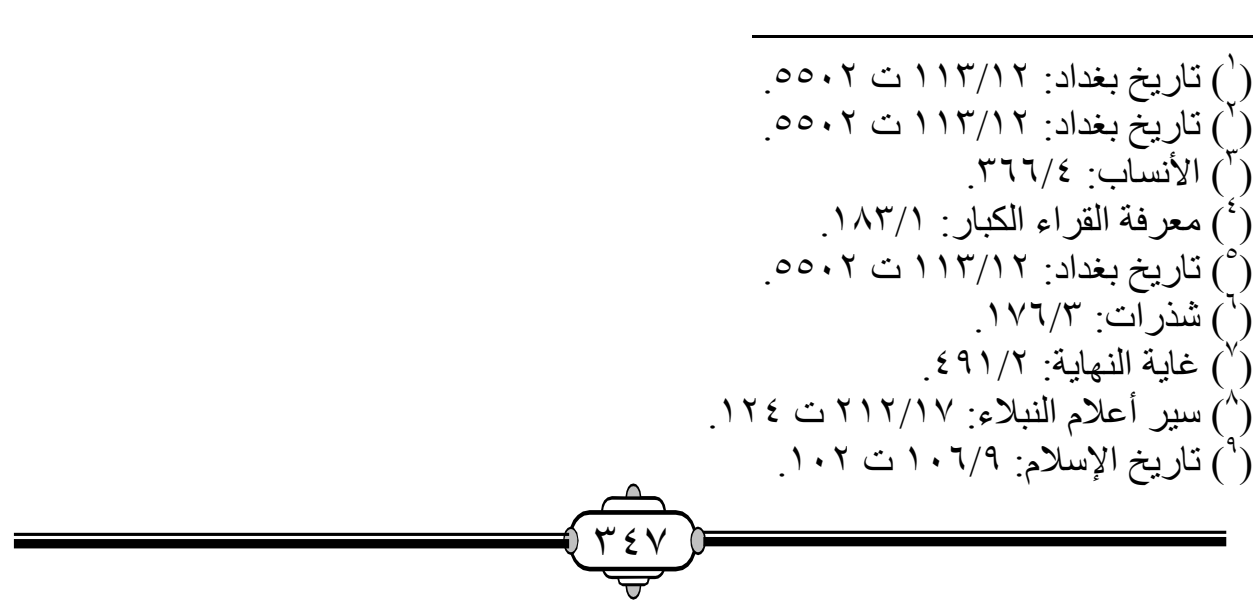




\section{شيوخ العراق ومن سار ذكره في الآفاق(').}

\section{فاصة مال الراوبي:}

وثقه العتيقي بسماع الخطيب له ووثقه الخطيب، ومن ترجم له من الأئمة وتكلموا عليه فهو بذلك مقبول الرواية محتجّج به بإجماع أهل النقد والله أعلم.

ع - عبد الواحلد بن جعفر بن أحمد أبو الفرج الناقد، حدث عن: أبي القاسم البغوي حدثي عنه أحمد بن ححم العتيقي، قال الخطيب: سألت العتيقي عنه فقال: ثقة (r)، وقال الذهبي: وعنه أحمد بن كحمد العتيقي، وقال: حدثنا في هذه السنة وكان ثقة (ॅ).

\section{فاصة حال الراوبs:}

انغرد العتيقي بتوثيق عبد الواحد بن جعفر فيما سأله عنه الخطيب البغدادي ونقل ذللك الإمام الذهبي في تاريخه، فالراوي مقبول الرواية بسبب توثيق العتيقي للراوي صراحة والذهبي ضمنًا و الله أعلم.

\section{هـ- عمر بن محمل بن عبد الله بن خلف بن بخيت أبو القاسه الدقاق، حدث عن:} الحسين بن إسماعيل المحاملي، وإسماعيل بن محمد الصفار، حدثني عنه العتيقي بل بلهي

وسألته عنه فقال: ثقة كان عنده شيء يسير (ء).

\section{خلاصة مال الراويى:}

الثي اليسير للراوي في الحديث لا يؤخذ عليه، فالراوي ثقة بسؤال الخطيب عنه الإمام العتيقي وهذا الرأي ممن انغرد به العتيقي من حيث التوثيق والكلام عليه، والله أعلم.

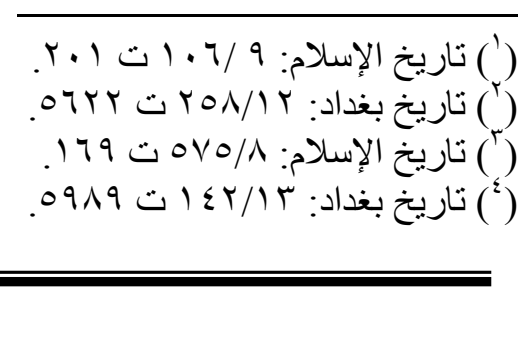


7ه- - عثمان بن جعفر بن محمد بن الحسين بن عبد القادر أبو عمر الجواليقي (') حدث

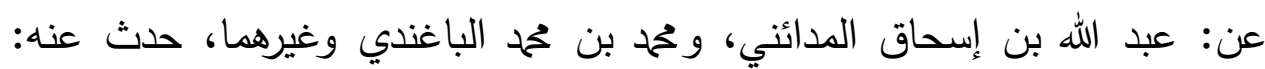
القاضي أبو العلاء الواسطي، والعتيقي وغيرهما، قال الخطيب: سألت العتيقي عنه فقال كان ثقة(r)، وذكر الذهبي توثيق العتيقي (r).

\section{هل1صة مال الراوي:}

الخطيب يسأل عن عثمان بن جعفر شيخه العتيقي فتكون الإجابة منه بالتوثيق له، وينقل ذلك التوثيق الذهبي في تاريخه فيقبل الراوي بتوثيق العتيقي ونقل الذهبي ذللك و الله أعلم.

-OV علي بن أحمد بن جعفر بن أبي حفص يعرف بابن النسائي ويكنى أبا الحسن، حدث عن: أحمد بن علي بن العلاء والجوزجاني وهحمد بن مخلد وغيرهما، حدثا عنه العتيقي، قال الخطيب: سألت عنه فقال كان صحيح السماع(£).

\section{فلاصة مال الراوي:}

صحيح السماع من دلائل قبول الراوي والاحتجاج به هذا ما أجاب به العتيقي على سؤال تلميذه عن علي بن أحمد بن جعفر و الله أعلم.

هـ- علي بن أحمد بن بختيار أبو الحسن المقرئ الضرير، حدث عن: إسماعيل

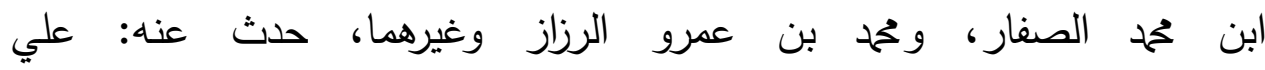
ابن طلحة بن البصري، وأحمد بن محه العتيقي وغيرهما، قال الخطيب: سألت

(') الجَوَ الِيْيّي: بفتح الجيم و الواو وكسر اللام بعد الألف وسكون الياء المنقوطة باثنتين من تحتها

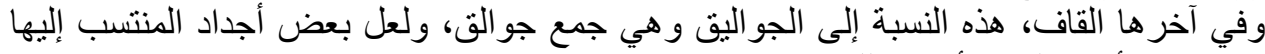

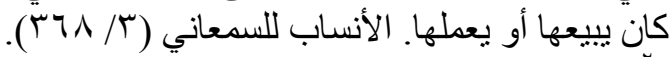

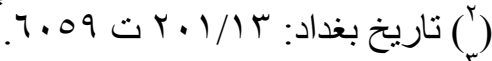

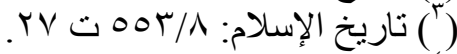

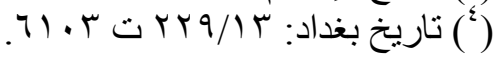


العتيقي عنه فقال: كان شيخًا صالحًا ثقة (').

\section{فاصة مال الراوبي:}

جمع علي بن أحمد بن بختيار ألفاظًا ثلاثة شيخًا، وصالحًا، وثقة، وهكذا أجاب العتيقي الخطيب عند سؤاله عن هذا الراوي فمن جمع هذه الأوصاف جدير بأن يكون مقبولًا و الله أعلم.

9ه- علي بن بلد أبو الحسن، حدث عن: أحمد بن الفضل بن خزيمة، وعلي ابن كحه بن الزبير الكوفي وغيرهما، حدثنا عنه العتيقي وسألته عنه فقال: كان شيخًا

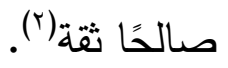

\section{فلاصة مال الراوي!:}

وعند اجتماع ثلاثة ألفاظ في الراوي الشيخ والصلاح والثقة تكون درجة الراوي عند العتيقي فوق غيره والله أعلم، فاجتماع الألفاظ الثلاثة في الراوي من دلائل القبول و الله أعلم.

• ـ - علي بن الحسن بن علي بن الحسن أبو الحسن المعروف بابن الرازي، حدث عن: عحمد بن القاسم بن زكريا الكوفي، وأحمد بن علي الجوزجاني وغيرهما، حدث عنه: الأزهري، وحمح بن أحمد بن شعيب الروياني وغيرهما، قال الخطيب: سألت العتيقي عن علي

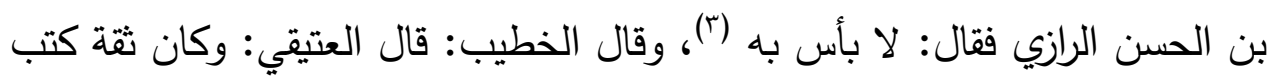
الكثير توفى سنة إحدى وتسعين وثلاث مائة (؛)، قال الخطيب: قال لي الأزهري كان علي بن الحسن الرازي فقيرًا وراقًا يحضر معنا السماع من ابن حيوة وكان

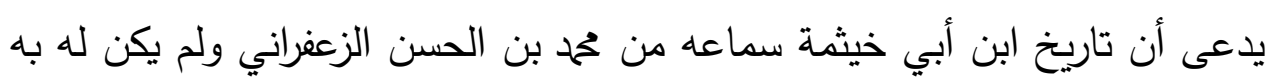

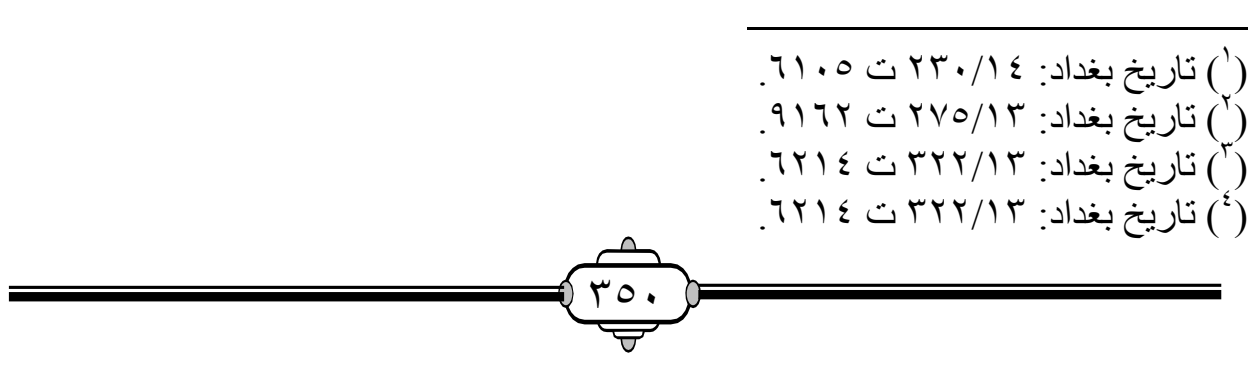




\section{الإقتاع بما نقله الخطيب عن شيخه العتيقي}

كتاب وذكره لي الأزهري مرة أخرى فقال كذاب لا يسوي شيئًا (') وقال الخطيب: قلت للعتيقي إن أبا القاسم الأزهري يسيء القول فيه فقال ما علمت منه إلا خيرًا قد

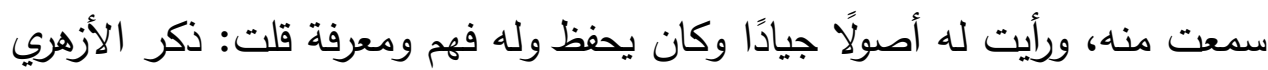
أنه لم يكن له أصل بتاريخ ابن أبي خيثمة فقال لم أسمع التاريخ ولم أعلم هل كان له به أصل أم لا، وذكرت للأزهري كلام العتيقي هذا فقال: العقيقي يتساهل في أمر إن الته الثيوخ(ז)، وقال الخطيب: سألت القاضي أبا عبد الله الصيمري عن الرازي فأثنى عليه خيرًا قلت: هل كان له اصل بتاريخ ابن أبي خيثمة فقال نعم، كان يفهم(ب)، وقال ابن أبي الفوارس: كان أبو الحسن بن الرازي ذاهب الحديث لا يسوي قليلًا أو كثيرًا (ఓ) وذكره الذهبي وقال قال الأزهري كذاب ووثقه العتيقي وغيره(0) وذكر ابن حجر كلام الأئمة السابقين (†).

\section{فاصة حال الراوبs:}

العتيقي ذكره مرتين عن طريق سؤال الخطيب له وبقول الخطيب قال العتيقي: الأولى قال عنه لا بأس به والثاني قال ثقة فتغير قول العتيقي فيه ما بين قبوله من فن

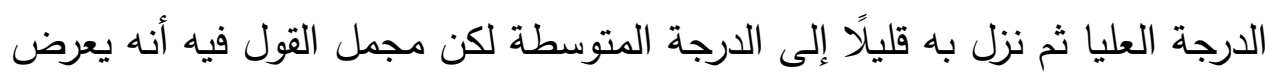
حديثه على غيره من الثقات فما وافقهم فيه كان مقبول الرواية، وما كان غير ذلك يكون مردود الرواية، و الله أعلم.

اج- علي بن الحسن بن علي أبو الحسيز الشيباني، حدث عن: الحسين

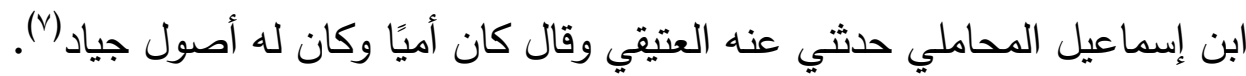

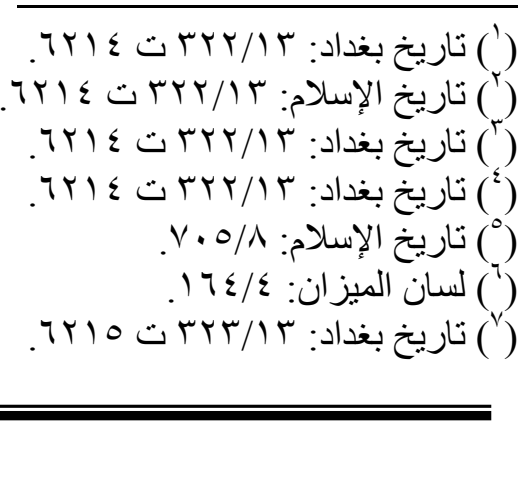


مفاد كلام العتيقي الذي نقله الخطيب عنه بقوله وكان أميًا وكان له أصول جياد، أن ما كان من أصوله فهو مقبول الرواية وما كان غير ذلك لا يقبل فمن ثبت بعل سماعه من أصوله فهو مقبول وإلا كان مردودًا و الله أعلم

r r - علي بن سهل بن محمد بن أبي حيان بن سهل بن غليط بن الصباح بن أبي ذر ابن أبي الصهباء أبو الحسن التيمي الكوفي، حدث عن: عبد الله بن زيدان البجلي وعبد الله بن ثابت الحريري، قال الخطيب: سألت العتيقي عن علي ابن سهل قال ثقة فاضل

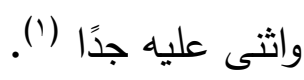

\section{فاصة حال الراوبي:}

بعد توثيق العتيقي الذي نقله عنه الخطيب في تاريخه بقوله سألت العتيقي أضاف إليه الفضل والثناء عليه جدًا فهذا من مؤشرات قبول الراوي من الدرجة العليا، و الله أعلم.

باج- علي بن العباس بن عثمان بن سعدويه أبو الحسن البرداني (r) الشاهد، حدث عن: أبي سعيد بن الأعرابي، وأحمد بن إبراهيم الموصلي وغيرهما، حدث عنه: العتيقي والخلال، قال الخطيب: سألته عنه فقال صالح ().

\section{فلاصة مال الراوي:}

درجة صالح الذي أعطاها الإمام العتيقي للراوي بسؤال الخطيب له تحتاج إلى متابع له في هذه الدرجة وإلا كان ضعيفًا فلابد لله من عاضد ومتابع يقويه.

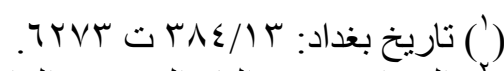

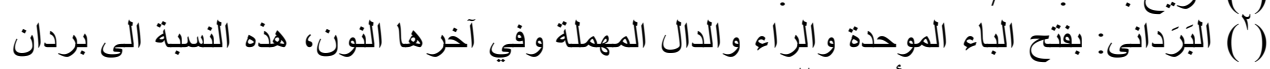

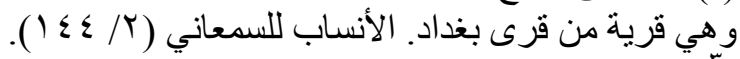

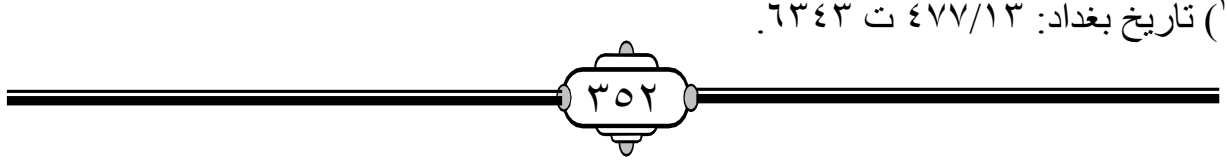




\section{الإقناع بما نقله الخطيب عن شيخه العتيقي}

ع ج - علي بن الفضل بن إدريس بن الحسين بن محمد أبو الحسن الستوري (')، سكن بغداد وحدث بها عن: الحسن بن عرفة أحاديث يسيرة، روى عنه: يوسف القواس، والحسين بن عمر بن برقان الغزال وغيرهما، قال الخطيب: سمعت العتيقي ذكر علي بن الفضل الستوري فقال: ثقة ما سمعت شيوخنا يذكرونه إلا بجميل توفى سنة ثلاث وأربعين وثلاث مائة(r) وذكر الذهبي توثيق العتيقي (r)، ونقل الذهبي كلام

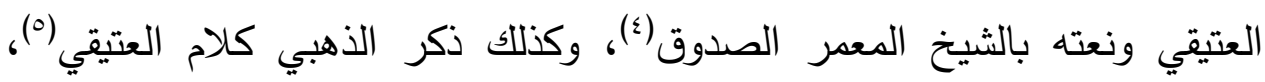

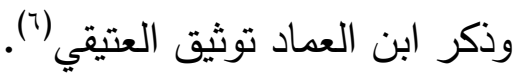

\section{خلاصة مال الراوي:}

هكذا جاء توثيق العتيقي عن طريق سماع الخطيب له، وانغرد العتيقي بذلك لكن نقل الذهبي قوله في أكثر من مصدر، وابن العماد الحنبلي فيضاف إلى توثيق العتيقي الصريح توثيق هؤلاء الأئمة الضمني للراوي و الله أعلم.

ه7 - علي بن محمد بن سعيد بن العباس بن دينار أبو الحسن الكندي الرزاز، سمع: أبا شعيب الحراني، وعلي بن حسنوبه القطان وغيرهما، حدث عنه: البرقاني، والعتيقي وغيرهما، قال الخطيب: قال العتيقي: كان ثقة أمينًا مستورًا له أصول حسان حسان توفى أنى سنة اثنتين وسبعين وثلاث مائة (`) وأشار الذهبي إلى قول العتيقي (^).

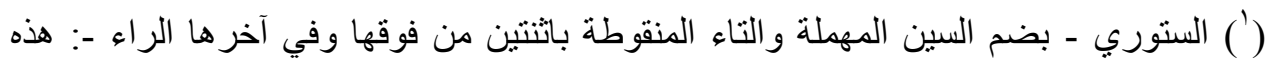

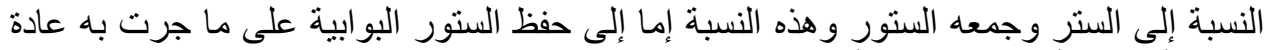

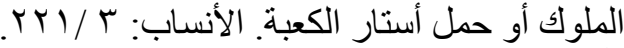
(T)

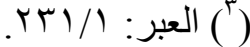
(q) سير أعلام النبلاء:

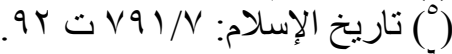

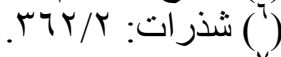

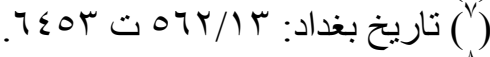

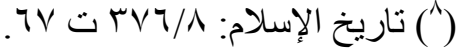




\section{فلاصة مال الراوي:}

انفرد العتيقي بالحديث عن علي بن حمح بن سعيد والذي مفاده القبول والاحتجاج ونقل الذهبي لذلك القول عن هذا الراوي يعتبر تقوية وموافقة منه لكلام العتيقي وقد نقل ذلك الخطيب عن شيخه العتيقي بقوله قال العتيقي، و الله أعلم. 7 7 - عب بن عمرو بن جعفر بن أحمد بن محمد ابو النضر البلخي، سكن بغداد وحدث بها

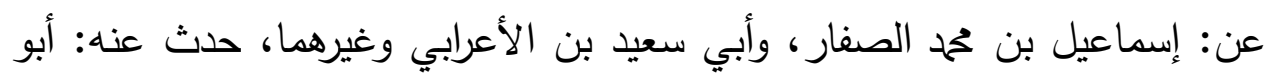
محمد الخلال، والتتوخي وغيرهما، قال الخطيب: قال العتيقي: فيه تساهل في الحديث(')، وقال الخطيب: كان غير ثقة، وقال ابن أبي الفوارس: كان سيء الحال

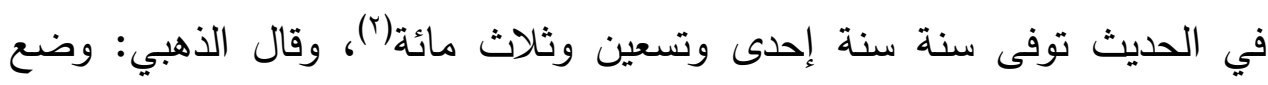

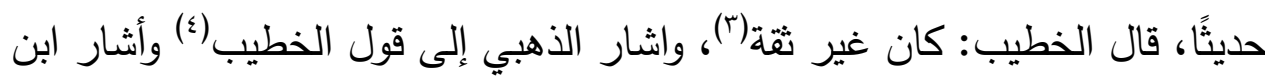
ابن حجر إلى أقوال الخطيب والعتيقي وابن أبي الفوارس(ه).

\section{فاصة مال الراوبي:}

تساهل العتيقي الذي نقله عنه الخطيب في تاريخه بقوله قال العتيقي: وبذكره أنه غير ثقة وجرحه من بعض العلماء ونقله البعض عنهم لحري بعدم قبول قوله على سبيل التثرد فلابد له من متابع حتى يقبل حديثه و الله أعلم.

V V - المعافي بن زكريا بن يحيى بن حميل بن حماد بن داود أبو الفرج النهرواني (؟) القاضي

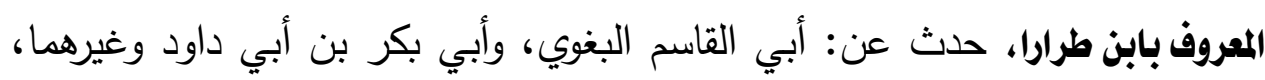

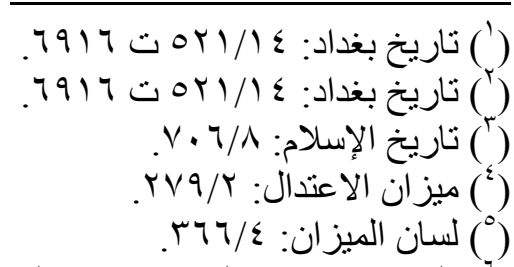

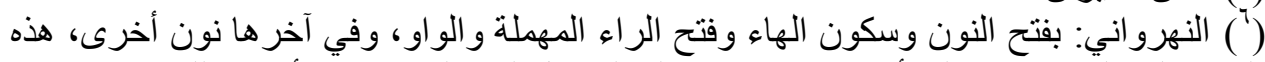

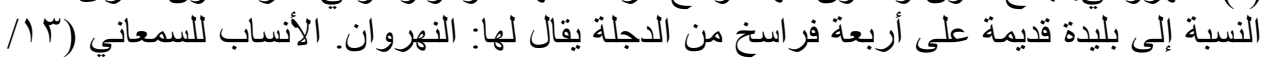


حدث عنه: أبو القاسم الأزهري، وأبو الطيب الطبري وغيرهما، قال الخطيب: قال العتيقي: كان ثقة توفى سنة تسعين وثلاث مائة(')، وقال الخطيب: كان من أعلم وعليري

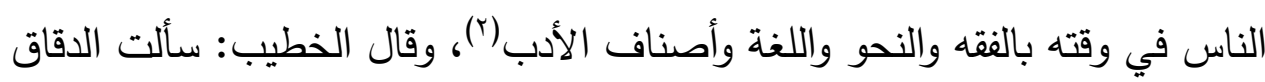

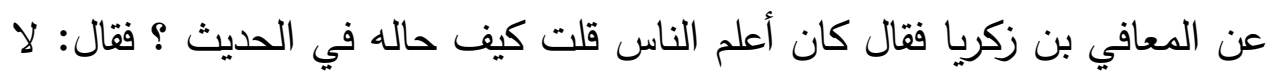
أعرف حاله قال البرقاني لكن كان كثير الرواية للأحاديث التي تميل إلى الثيعة الثيا

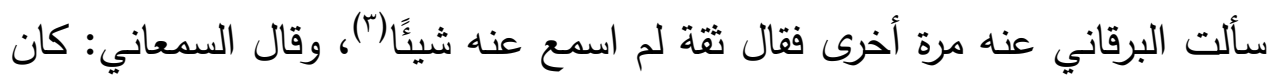
من مشاهير العلماء والمتقنين وقال ابن ماكولا: كان آية في الحفظ والمعرفة والتفنن

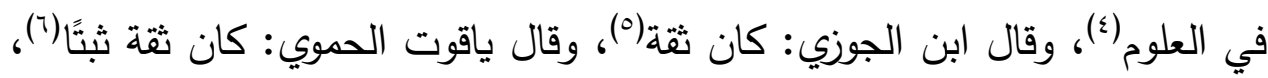

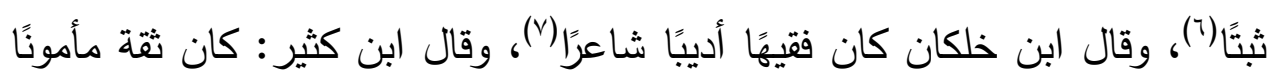
عالمًا كثير الأدب والتمكن من أصناف العلوم وله المصنفات الكثيرة(^)، وقال السيوطي: ثقة ولي القضاء(9) وقال ابن العماد: أكثر وجمع فأوعى وبرع(·').

\section{فلاصة مال الراوبي:}

مجمل القول في هذا الراوي القبول والاحتجاج به، وما ذكر فيه من تشيع لم يثبت كونه داعية له، وقد جاء قول العلماء موافقًا لقول العتيقي الذي نقله عنه الخطيب البغدادي في تاريخ بقوله قال العتيقي: و الله أعلم. 1 - - نصر بن غالب بن إسحاق بن إبراهيم بن يعقوب أبو الفتح البزار، حدث عن: أبي

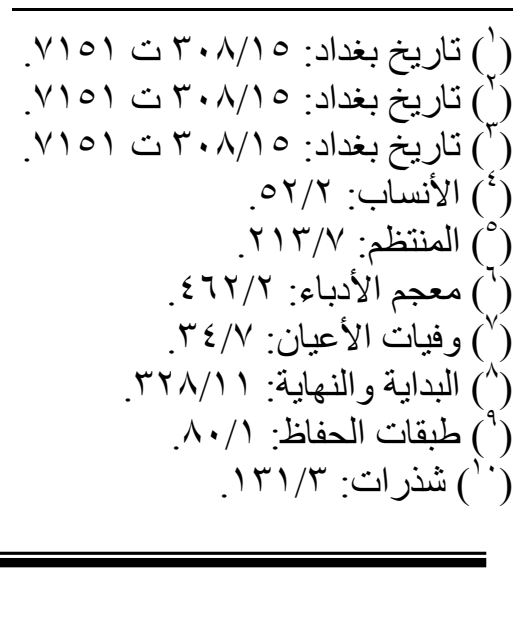




\section{الإقناع بما نقله الخطيب عن شيخه العتيقي}

القاسم البغوي، وأبي بكر بن أبي داود وغيرهما، حدث عنه: العتيقي، وأحمد علي

التوزي، قال الخطيب: قال العتيقي: كان ثقة توفى سنة أربع وثمانين وثلاث مائة ( )

$$
\text { (') وذكره الذهبي بدون تعديل أو تجريح(؟). }
$$

\section{فاصة مال الراوبي:}

نقل الخطيب هذا القول عن شيخه العتيقي بلفظ قال، وهي من ألفاظ وصيخ الأداء للسماع من لفظ الثيخ وهي أرفع أقسام التحمل وألفاظ الأداء، وكان النقل منه بالتوثيق للراوي وبذلك يكون الراوي مقبول الرواية محتجًا به وكان ذلك مما انغرد العتيقي بالكلام عنه و الله أعلم.

9 79- هماه بن الصقر أبو علي الموصلي، سكن بغداد وحدث بها عن: محم ابن العباس بن الفضل الخياط وحدث عنه العتيقي، وسألته عنه فقال:كان

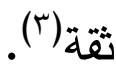

\section{فاسة مال الراوبي:}

سأل التلميذ شيخه عن راو من الرواة لمعرفة قدر وقيمة هذا الراوي وكان ذلك مباشرة دون واسطة فكانت إجابة الثيخ بقبول الراوي والاحتجاج به وكان ذلك مدن انغرد به العتيقي لهذا الراوي حيث لم نجد لغيره توثيقًا والله أعلم.

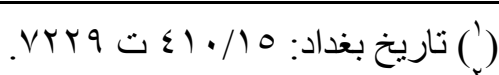

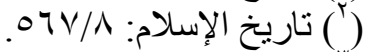

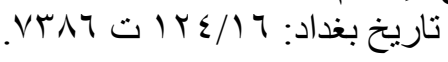




\section{خاتمة البمث}

نسأل الله عز وجل حسنها وأولادنا وأهلينا وسائر المسلمين وبعد تمام نعمة الله علينا بفضله وإحسانه بإتمام هذا البحث المسمى: [الإمتاع بما نقله الخطيب عن العتيقي بالقول

\section{والتحليث والسؤال والسماع].}

نود أن نستعرض مع القارئ تلك النتائج المستنبطة من هذا البحث: بلغ عدد ما نقله الخطيب في تاريخه عن العتيقي بالصيخ المذكورة 79 تسع

$$
\text { وستون راويًا، وجاء على النحو الآتي: }
$$

أ) جاء فيه بصيغة حدثنا، حدثني، حدثنيه، حدثنا عنه في عشر مواضع. ب) جاء فيه بصيغة قال في ثلاثة وعشرين موضعًا.

$$
\begin{aligned}
& \text { ج) جاء فيه بصيغة قال لي، قال لنا في ثمانية مواضع. } \\
& \text { د) جاء فيه بصيغة سمعت في مواضع أربعة. }
\end{aligned}
$$

هـ) جاء فيه بصيغة سألت وسألته وسألت عنه في أربعة وعشرين موضعًا. و) انفرد الإمام العتيقي بالكلام على بعض الرواة دون غيره من الأئمة لبعض له له الرواة المترجم لهم في بطون الكتب.

$$
\text { ز) نوهت على كلام غيره من العلماء والنقاد في الرواة. }
$$

اعتمدت في ذكر كلام العلماء في البحث على الكثير من المصادر المعتمدة

$$
\text { في ترجمة الرواة. }
$$

استخرجت هؤلاء العلماء من كتاب تاريخ بغداد للخطيب البغدادي.

ذكرت خلاصة تحدد معالم الرواة بشيء من الإنصاف.

قارنت بين قول العتيقي وغيره من الأئمة النقاد.

الإمام العتيقي وافق قوله قول غيره من الأئمة إلا ما ندر.

شخصية الإمام العتيقي ضمن علماء الجرح والتعديل واضحة وبارزة في

صفوف علماء عصره.

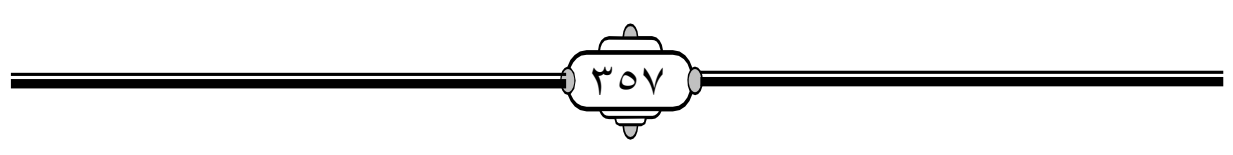


تأثر الكثير من العلماء في عصره وبعد عصره بالإمام العتيقي.

الإمام العتيقي من علماء الجرح والتعديل في القرن الخامس الهجري.

( ( ) يعتبر العتيقي من العلماء المتوسطين في أقواله في الجرح والتعديل.

(1) (1) استعمل الإمام العتيقي الكثير من ألفاظ الجرح والتعديل.

(Y ( ) الخطيب البغدادي نقل كلام شيخه العتيقي بالصيخ التي تدل على السماع

المباشر والتلقي عنه من غير واسطة.

وأخيرًا أوصي غيري من الباحثين في مجال التخصص أخذ هذه العالم بتوسع في

رسالة علمية يجمع بها شتات أقواله جميعًا من مصادر كتب التراجم خاصة فهو لله التأثير الواضح على تلاميذه وغيرهم وأصحاب المؤلفات مثل الذهبي والسمعاني وابن الأثير وغيرهم من أصحاب المؤلفات بعده. و الله ولي التوفيق

الحمد لله حتى يبلغ الحمد منتهاه

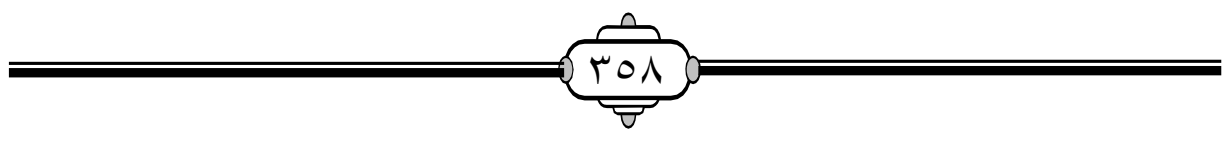




\section{فهرس الرواة}

ا ـ عحم بن أحمد بن أبي حسان أبو الحسن المؤدب

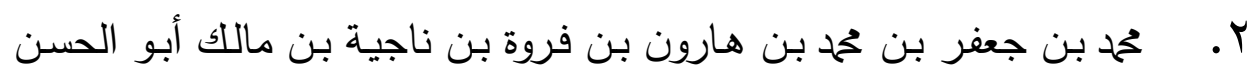

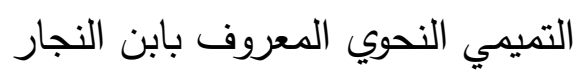

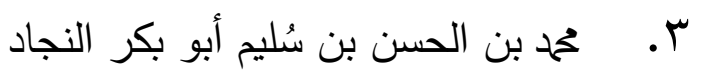
ـ. حمد بن الصقر بن يحيى بن السري بن ثروان أبو بكر الموصلي عم شيخنا حمح بن همام بن الصقر

ه. محهد بن عبد الله بن ححمد بن إسحاق بن حسان أبو عبد الله الحريري

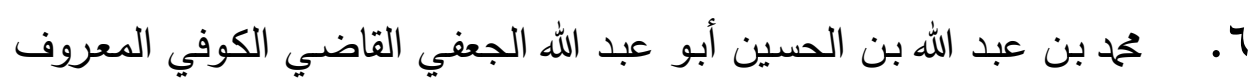

$$
\text { بابن الهرواني }
$$

V. محمد بن عبد الله بن إسحاق أبو الفرج القاضي المعروف بالعماني

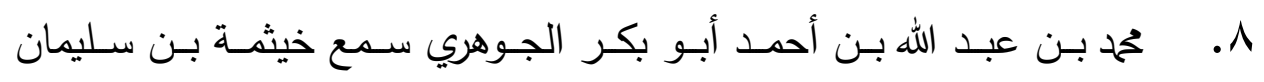
الأطرابلس

9 ـ محمد بن عبد الله بن أحمد بن القاسم بن جامع أبو أحمد الدهان

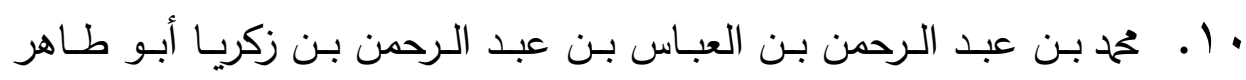
المخلص

1 ا ـ محمد بن عبد الرحمن بن جعفر بن عمر أبو بكر الصوفي

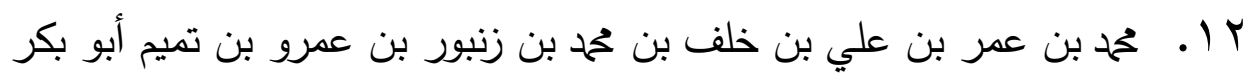
الوراق

سا ـ عحمد بن عثمان بن عبيد بن الخطاب أبو الطيب الصيدلاني

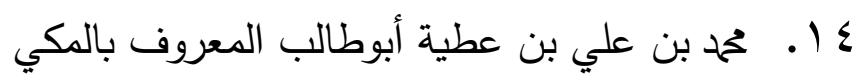

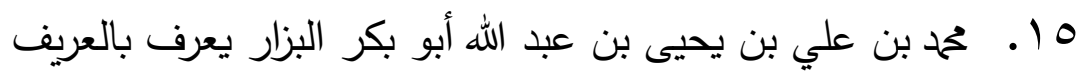

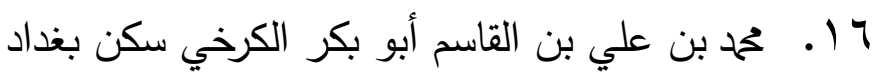

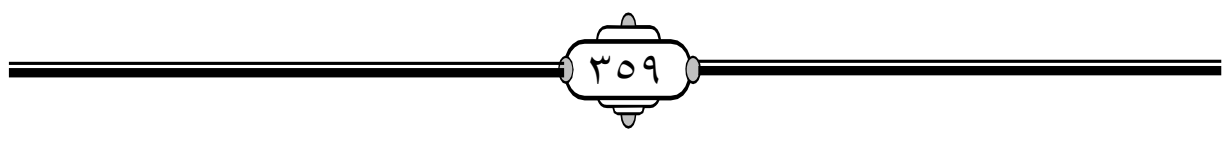




\section{الإقناع بما نقله الخطيب عن شيخه العتيقي}

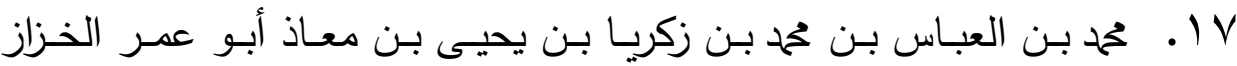

$$
\text { المعروف بابن حيوية }
$$

1 ا ـ محمد بن ححمد بن عمر بن أحمد بن خُشَيْش أبو أحمد

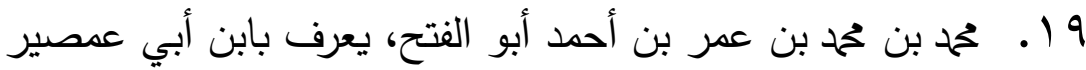

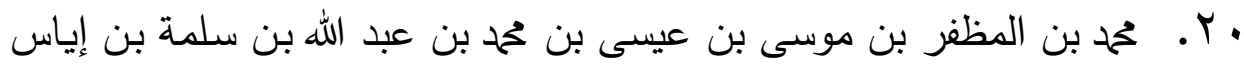

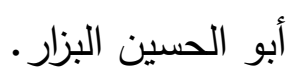

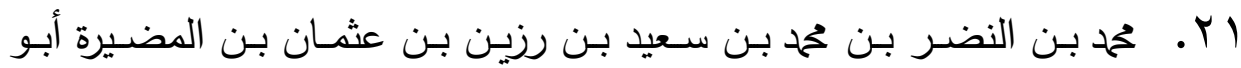

$$
\text { الحسين النخاس الموصلي }
$$

r Y . . حمح بن يوسف بن حمد أبو بكر العلاف يعرف بابن دوست

ب r . محمد بن يحيى بن مهدي أبو عبد الله الجرجاني

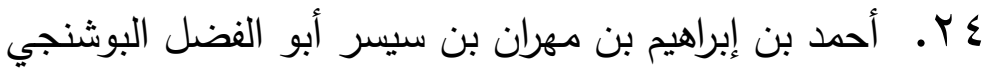

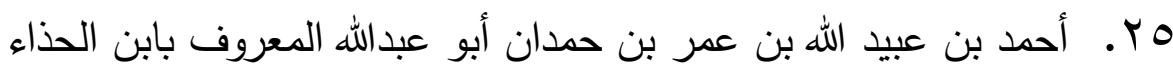
TY. أحمد بن عمر بن عحم بن خرشيذ قوله أبو علي الأصبهاني Y YV

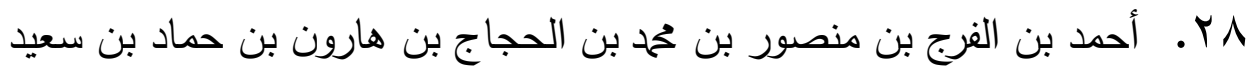
بن الصلت بن أبان أبو الحسن الفارسي الوراق 9 r. أحمد بن حمد بن أبي موسى أبو بكر الهاشمي

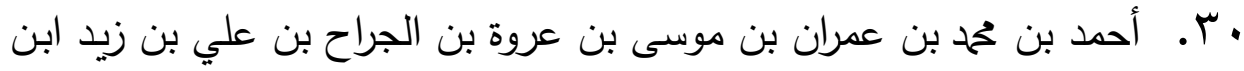
بكر بن حريش أبو الحسن النهشلي ويعرف بابن الجندي

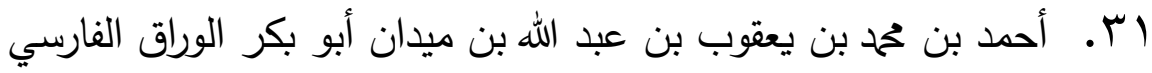
r r. إسماعيل بن سعيد بن إسماعيل بن حمح بن سويد أبو القاسم المعدل جـ

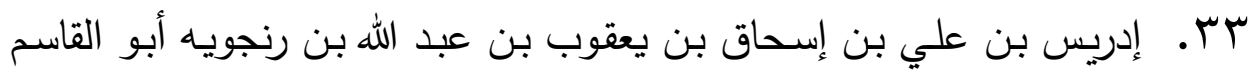

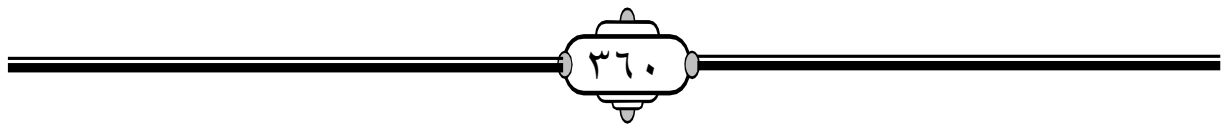




\section{الإقناع بما نقله الخطيب عن شيخه العتيقي}

ع ا. جعفر بن محمد بن علي بن الحسين بن إسماعيل بن إبراهيم بن مصعب بن

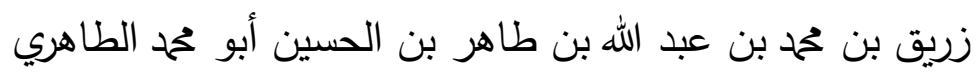

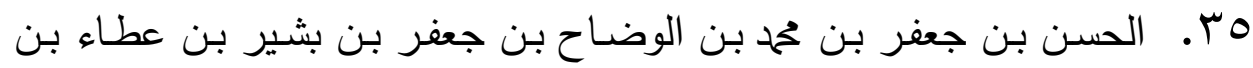

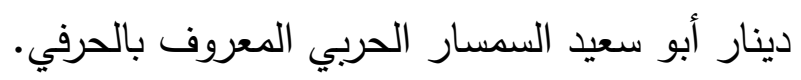

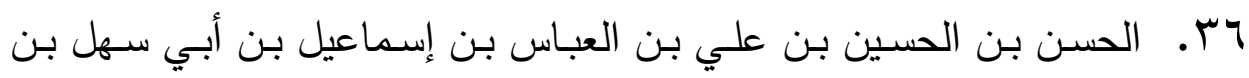

$$
\text { نوبخت أبو حمد النوبختي الكاتب بن بن بن }
$$

rV ^r. الحسن بن ححمد بن بشران أبو عحمد روى عن القاضي المحاملي و عحمد بن مخلد

$$
\text { الدوري }
$$

و ب. الحسين بن جعفر بن محمد أبو القاسم الواعظ المعروف بالوزان • ـ. الحسين بن علي بن سهل بن وهب أبو القاسم السمسار

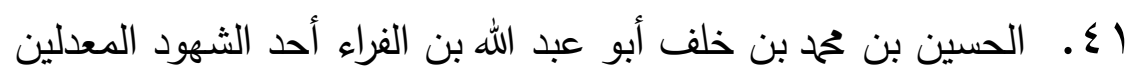

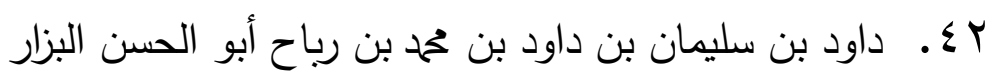
س ع. سهل بن أحمد بن عبد الله بن سهل أبو حمه الديباجي

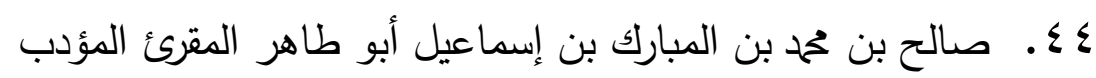
○ــ ـ الطيب بن يمن بن عبد الله أبو القاسم مولى المعتضد بالله 7 ؟ . عبد الله بن أحمد بن حمحد بن عبد الله أبو الحسين المقرئ الأصبهاني

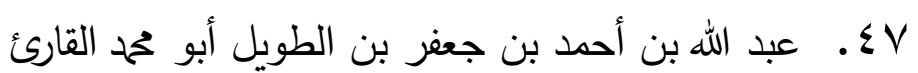
^ ـ. عبد الله بن الحسين بن عبد الله أبو عحم الخلال يعرف بابن الشيلماني

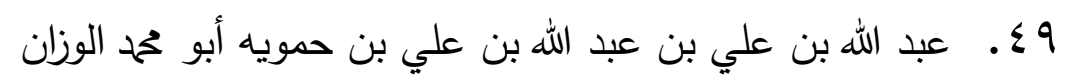

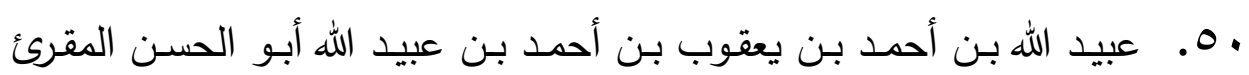
يعرف بابن البوا 10. عبيد الله بن خليفة بن شداد أبو أحمد البلدي ليولي

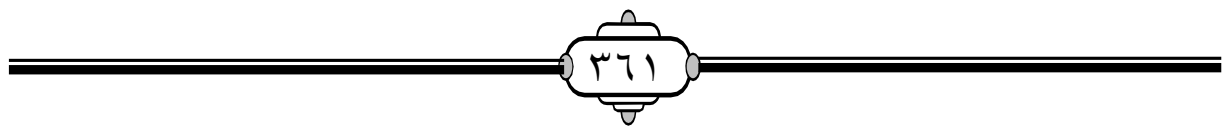




\section{الإقناع بما نقله الخطيب عن شيخه العتيقي}

ro . عبيد الله بن محمد إسحاق بن سليمان بن مخلد بن إبراهيم بن مروان بن حباب

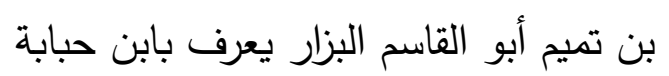

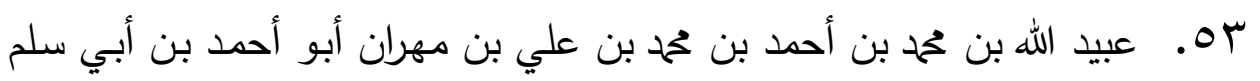

$$
\text { الفرضي المقرئ }
$$

§. ـ. عبد الواحد بن جعفر بن أحمد أبو الفرج الناقد

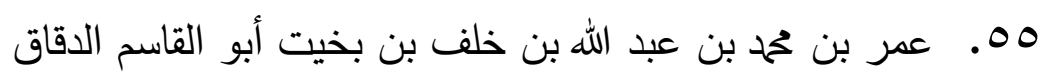

7ه. عثمان بن جعفر بن محمد بن الحسين بن عبد القادر أبو عمر الجواليقي

OV

$$
\text { الحسن }
$$

هـ هـ علي بن أحمد بن بختيار أبو الحسن المقرئ الضرير

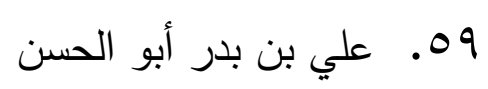

• 7. علي بن الحسن بن علي بن الحسن أبو الحسن المعروف بابن الرازي

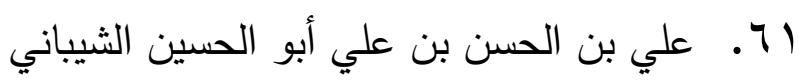

T T. علي بن سهل بن محهد بن أبي حيان بن سهل بن غليط بن الصباح بن أبي

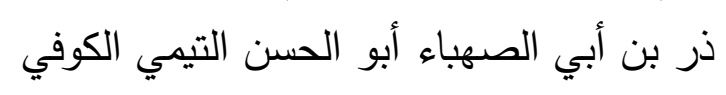

سا7. علي بن العباس بن عثمان بن سعدويه أبو الحسن البرداني الثاهد

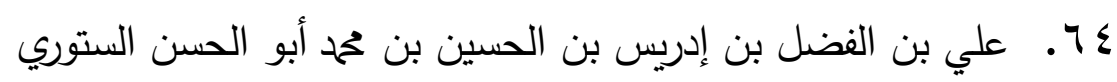

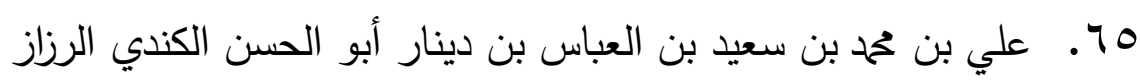

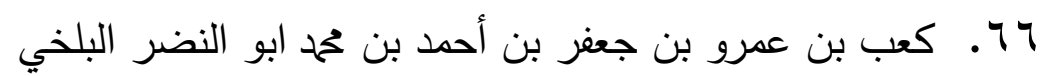

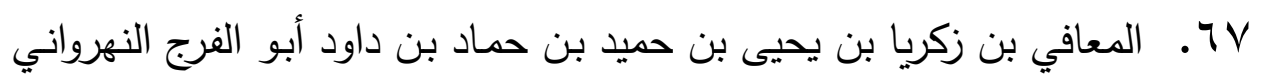

$$
\text { القاضي المعروف بابن طرارا }
$$

1 7 ـ نصر بن غالب بن إسحاق بن إبراهيم بن يعقوب أبو الفتح البزار 9 7.

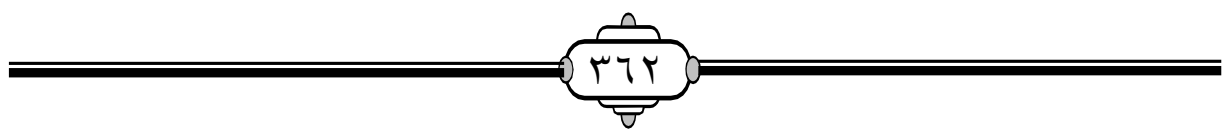




\section{الإقناع بما نقله الخطيب عن شيخه العتيقي}

\section{المسادر والمراجع}

( ) (إنباه الرواة على أنباه النحاة لجمال الدين أبو الحسن علي بن يوسف القفطي

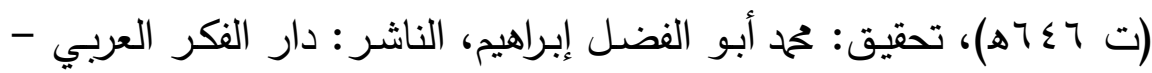

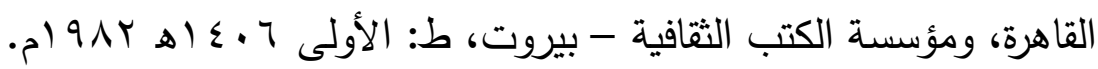
الانساب للإمام أبي سعد عبد الكريم بن حمح السمعاني (ت ب ب07ه)، تقديم:

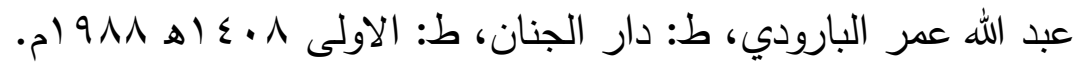
البداية والنهاية، المؤلف: أبو الفداء إسماعيل بن عمر بن كثير (ت ع ع هـ)،

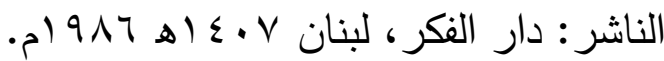
تاريخ الإسلام وَوَفيات المشاهير وَالأعلام، المؤلف: شمس الدين أبو عبد الله

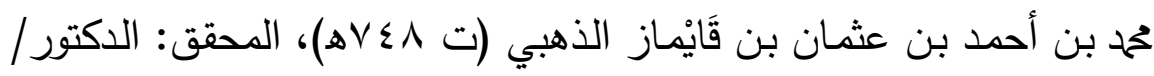

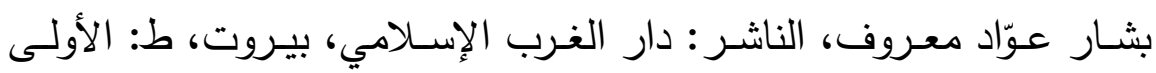

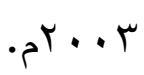
تاريخ بغداد، المؤلف: أبو بكر أحمد بن علي بن ثابت الخطيب البغدادي

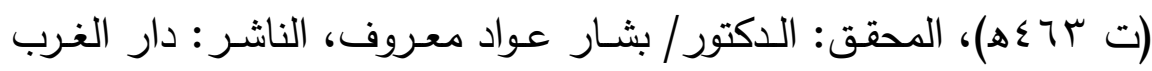

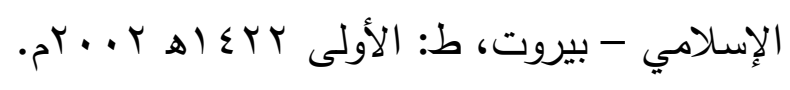

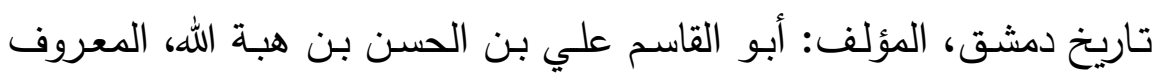
بابن عساكر (ت المها)، تحقيق: أبي عبد الله علي عاشور الجنوبي، ط: دار إحياء التراث العربي، بيروت، ط: الأولى. تبصير المنتبه بتحرير المشتبه، المؤلف: أبو الفضل أحمد بن علي بن محهد

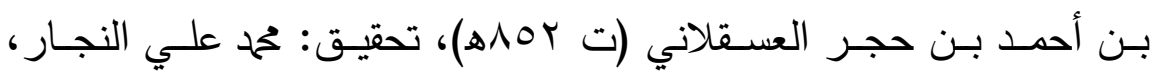
مراجعة: علي تحمد البجاوي، الناشر : المكتبة العلمية، بيروت - لبنان. تذكرة الحفاظ، الامام أبو عبد الله شمس الدين الذهبي، ط: دار احياء التراث

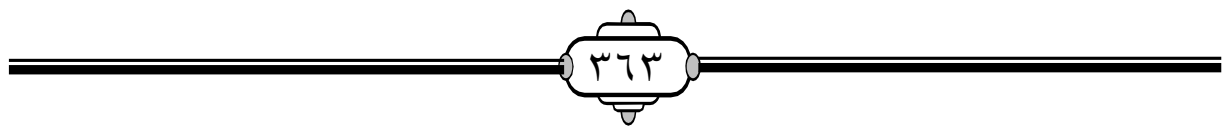




\section{الإقناع بما نقله الخطيب عن شيخه العتيقي}

تكملة الإكمال، المؤلف: محمد بن عبد الغني البغدادي أبو بكر، تحقيق: د/ عبد القيوم عبد رب النبي، دار النشر : جامعة أم القرى، مكة المكرمـة، ط:

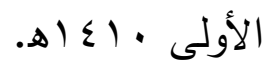

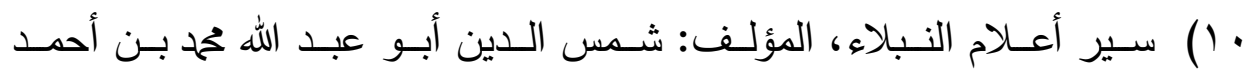

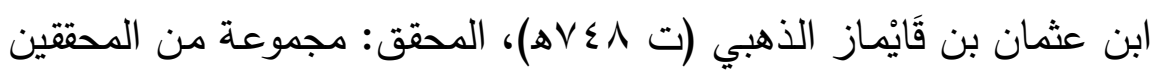
بإشـراف: الشـيخ شـعيب الأرنـاؤوط، الناشـر : مؤسسـة الرسـالة، بيـروت، طا: الثالثة 0.

(1) شذرات الذهب في أخبار من ذهب، أبو الفداء عبد الحي بن العماد الحنبلي (ت 19 • (اه)، تحقيق: لجنة إحياء التراث العربي، ط: دار الآفاق الجديدة، بيروت.

r Y ( ) طبقات الحفاظ، المؤلف: عبد الرحمن بن أبي بكر ، جلال الدين السيوطي

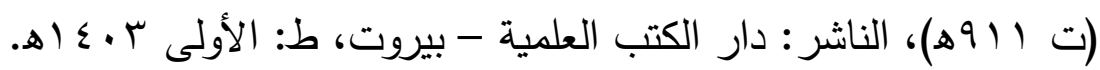

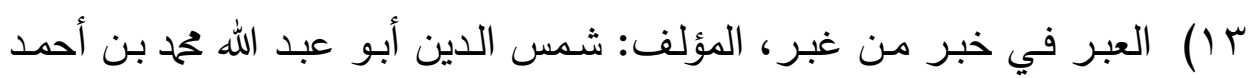

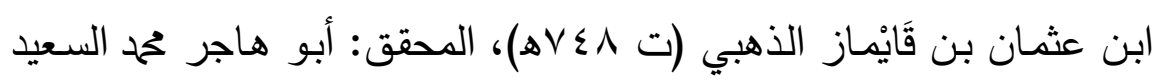
ابن بسيوني زغلول، الناشر : دار الكتب العلمية - بيروت. ع ( ) غاية النهاية في طبقات القراء لشمس الدين أبو الخير ابن الجزري، حمح بن محمد بن يوسف (ت بسره)، الناشر : مكتبة ابن تيمية، ط: عني بنشره لأول

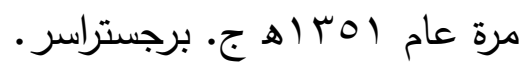
ه (الكامل في التاريخ، المؤلف: ابن الأثير، تحقيق: أبو الفداء عبد القاضي، ط: دار الكتب العلمية، بيروت.

7 (1) لب اللباب في تحرير الأنساب، المؤلف: عبد الرحمن بن أبي بكر، جلال الدين السيوطي (ت ال19ه)، الناشر: دار صادر - بيروت.

(IV اللباب في تهذيب الأنساب، المؤلف: أبو الحسن علي بن أبي الكرم حمد

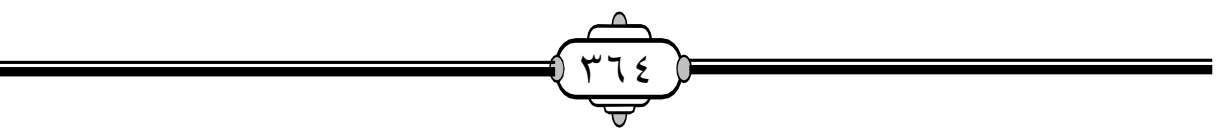




\section{الإقناع بما نقله الخطيب عن شيخه العتيقي}

ابـن تحمد بـن عبـد الكـريم بـن عبـد الواحـد الثـيباني الجـزري، عـز الـدين ابن الأثير (ت • بآه)، الناشر : دار صادر - بيروت.

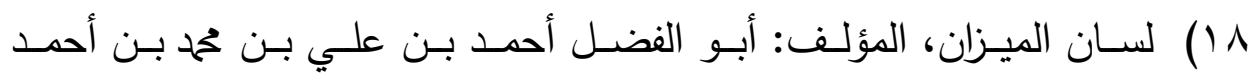
ابن حجر العسقلاني (ت مOr/or)، المحقق: دائرة المعارف النظامية - الهند،

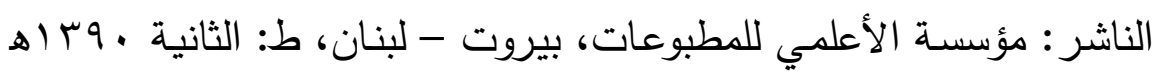
- م) 9 VI

مرآة الجنان وعبرة اليقظان في معرفة ما يعتبر من حوادث الزمان، أبو محمد $(19$

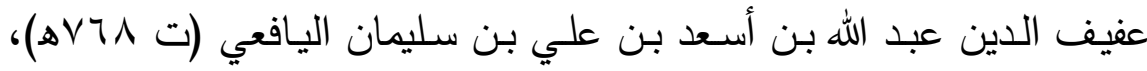
وضع حواشيه: خليل المنصور ، الناشر : دار الكتب العلمية، بيروت - لبنان،

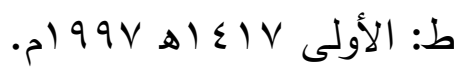
• معجم الأدباء = إرشاد الأريب إلى معرفة الأديب لشهاب الدين أبو عبد الله

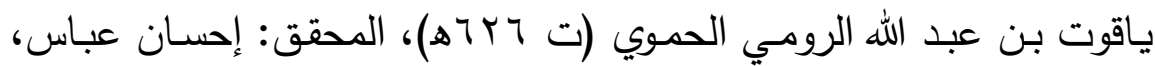

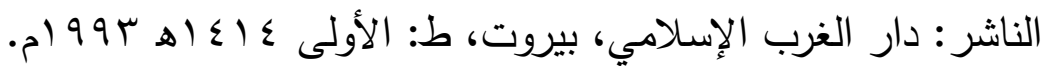
معجم المؤلفين، المؤلف: عمر رضا كحالة، الناشر : مكتبة المثنى - بيروت، دار إحياء التراث العربي، بيروت.

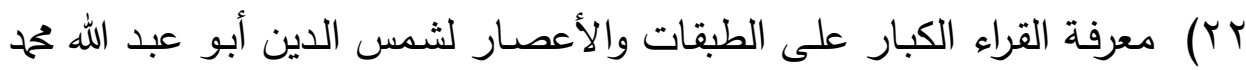

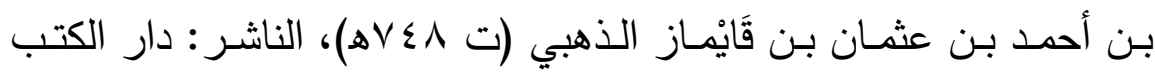

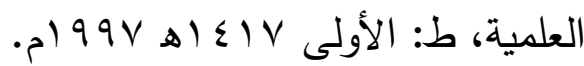

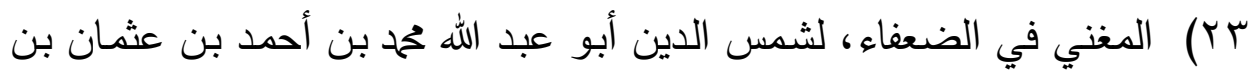

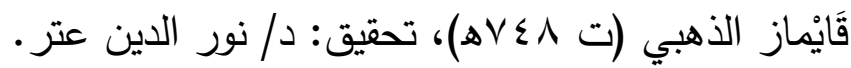
ع (Y) المنتظم في تاريخ الأمم والملوك، المؤلف: جمال الدين أبو الفرج عبدالرحمن

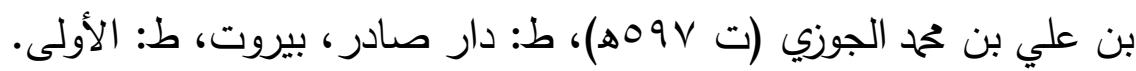
0 ميزان الاعتدال للإمـام الذهبي، تحقيق: علي ححمد البجاوي، ط: دار إحياء الكتب العلمية، عيسى البابي الحلبي، ط: الأولى. 170 


\section{الإقناع بما نقله الخطيب عن شيخه العتيقي}

TrY ) النجوم الزاهرة في ملوك مصر والقاهرة، المؤلف: يوسف بن تغري بردي ابن عبد الله الظاهري الحنفي، أبو المحاسن، جمال الدين (ت ع \&هـ)، الناشر : وزارة الثقافة والإرشاد القومي، دار الكتب، مصر • (YV (ت \&

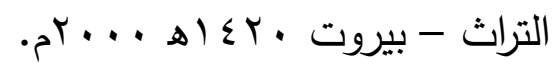

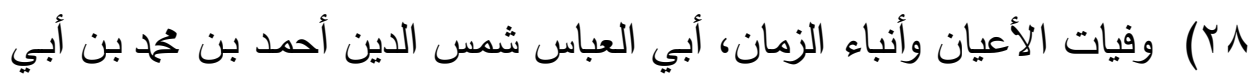

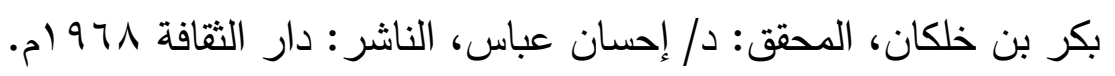

